NBER WORKING PAPER SERIES

\title{
REGIONAL ADJUSTMENT TO \\ TRADE LIBERALIZATION
}

Gordon H. Hanson

Working Paper No. 4713

\section{NATIONAL BUREAU OF ECONOMIC RESEARCH 1050 Massachusetts Avenue \\ Cambridge, MA 02138 \\ April 1994}

I thank Dan Hamermesh, Ann Harrison, Gerald Oettinger, Francisco Rivera-Batix, and seminar participants at MIT and Georgetown for helpful comments. All errors are my own. This paper is part of NBER's research program in International Trade and Investment. Any opinions expressed are those of the author and not those of the National Bureau of Economic Research. 
NBER Working Paper \#4713

April 1994

\title{
REGIONAL ADJUSTMENT TO \\ TRADE LIBERALIZATION
}

\begin{abstract}
In this paper, I study the effect of economic integration with the United States on stateindustry employment growth in Mexico. I disentangle the effects of two opposing forces on regional labor demand: transport-cost considerations, which, all else equal, encourage firms to relocate their activities to regions with relatively good access to foreign markets, and agglomeration economies, which, all else equal, reinforce the pre-trade pattern of industry location. I find that trade liberalization has strong effects on industry location. Consistent with the transport-costs hypothesis, post-trade employment growth is higher in state-industries that are relatively close to the United States. The results on agglomeration effects are mixed. Employment growth is higher where agglomeration in upstream and downstream industries is higher, but not where the agglomeration of firms in the same industry is higher. The results suggest trade liberalization has contributed to the decomposition of the manufacturing belt in and around Mexico City and the formation of broadly specialized industry centers located in northem Mexico, relatively close to the United States. The North American Free Trade Agreement is likely to reinforce these movements.
\end{abstract}

Gordon H. Hanson Department of Economics University of Texas Austin, TX 78712 and NBER 


\section{Introduction}

How do regions adjust to trade liberalization? In this paper, I study the effect of economic integration with the United States on state-industry employment growth in Mexico. I disentangle the relative effects of two opposing forces on regional labor demand: transport-cost considerations, which, all else equal, encourage firms to relocate their activities to regions with relatively low-cost access to foreign markets, and agglomeration economies, which, all else equal, tend to reinforce the pre-trade pattern of industry location.

That international trade causes a sectoral reallocation of resources is a basic insight of trade theory. Whether the motivation for trade is relative factor abundance, increasing returns to scale, or imperfect competition, the transition from an open economy to a closed economy alters a nation's pattern of specialization. The effect of trade on the spatial allocation of resources within a nation is less clear. Economists have begun to pay closer attention to patterns of regional specialization within countries, but there has been little cappirical work on how the transition to an open economy affects the location of economic activity.

A basic theme of recent literature is that externalities tie the productivity of agents in a location to the local agglomeration of resources. Dynamic externalities, due to knowledge spillovers or learning by doing, figure prominently in recent theories of economic growth Romer (1986 and 1990), Lucas (1988), Grossman and Helpman (1991), and Young (1991)). To the extent externalities are localized, regions with large agglomerations of firms grow relative to other regions. Several recent studies have found evidence that is consistent with externalities. Glaeser et al (1992) find U.S. city-industry growth is higher in cities with relatively diverse industrial bases; Jaffe. Trajtenberg, and Henderson (1993) find the creation of new patents is highly 
localized; and Rauch (1993b) finds that wages are higher in agglomerated regions.

Another strand of the literature emphasizes the role of market access in spatial resource allocation. Krugman (1991) shows the interaction of plant-level scale economies and transport costs can explain the formation of cities. In Rauch (1990), transport costs determine the volume of trade within and between countries. The importance of trade liberalization is that it changes the reference market for firms in a country. All else equal, we expect trade reform to shift resources to locations with relatively good access to foreign markets. With agglomeration economies, the size or mix of industries in a region may also affect how resident industries adjust to trade. To the extent closed-economy industry centers have relatively poor access to foreign markets, transport costs and agglomeration economies work in opposite directions.

The regional effects of trade liberalization are also a subject of considerable policy interest. The current trend towards economic integration is likely to reorganize the location of economic activity in developed and developing regions alike. The formation of the European Union and the fall of communism in Eastern Europe imply a substantial increase in regional resource mobility on the European continent. The spread of trade reform throughout the developing world has reoriented producers in these countries towards an entirely new set of markets. Wei (1993) finds that in China the fastest growing cities are those with relatively large export sectors. For obvious reasons, many of these cities are located in coastal areas relatively near Hong Kong and Taiwan. Regional movements in response to trade strain existing infrastructure and bring a dramatic realignment of relative regional fortunes. Commercial real estate prices in Shanghai, for instance, are now comparable to those in New York and Tokyo.

Recent changes in Mexico's trade policy make the country an ideal case study. In 1985, 
after four decades of import-substitution industrialization, Mexico began to open its economy to trade. The government enacted reform swiftly, eliminating most trade bariers in the following three years. Mexico's location in North America makes trade liberalization equivalent to economic integration with the United States. For Mexican firms, proximity to foreign markets means proximity to the U.S. market. Yet, Mexico's closed-economy production centers are located far from the United States. Since the 1950's, manufacturing capacity bas been concentrated in the country's interior, around Mexico City. While foreign-market access lures firms to the Mexico-U.S. border, the existing pattern of agglomeration works against this shift. I estimate the change in state-industry labor demand in Mexico before and after trade reform as a function of transport costs to the United States, industry agglomeration, and a series of control variables. If transport costs matter, employment growth will be high in regions close to the United States; if agglomeration economies matter, employment growth will be high in relatively large production centers. I study the effects of three types of agglomeration: withinindustry agglomeration, the concentration of firms in the same industry, related-industry agglomeration, the concentration of firms in upstream and downstream industries; and industrial diversity, the concentration of firms in a broad range of industries. No previous study separates relsted-industry agglomeration from within-industry agglomeration. I do so to assess whether the benefits of proximity to rivals differ from the those of proximity to buyers and suppliers.'

To preview the results, I find evidence of both transport-cost effects and agglomeration effects on post-trade employment growth. After trade liberalization, employment growth is higher in state-industries relatively close to the United States. The closed-economy manufacturing belt

\footnotetext{
1 Porter (1990) emphasizes that interactions between buyers and suppliers are an inportant component of the benefits firms derive from geographic concentration.
} 
around Mexico City is brealaing apart, as new industrial centers form closer to the Mexico-U.S. border. The North American Free Trade Agreement is only likely to reinforce this trend. Consistent with Glaeser et al, I find no evidence employment growth is higher where withinindustry agglomeration is higher, contrary to their results, I find no evidence employment growth is higher where industrial diversity is higher. A more novel finding is that employment growth is higher where related-industry agglomeration is higher. This is consistent with the hypothesis that the Mexican economy is changing from one based on a few large diversified industry centers to one based on a number of broadly specialized industry centers.

The body of the paper bas four sections. In section one, I review recent work in trade theory that relates to industry location. In section two, I describe regional-industrial employment growth in Mexico before and after trade reform. In section three, I give empirical results. In a final section, I offer concluding remarks.

\section{Theory}

\section{A. International Trade and Industry Location}

Most recent theories of interregional trade are based on several common elements: increasing returns to scale, transport costs, and congestion costs. In Asilis and Rivera-Batiz (1993), Fujita (1988), Krugman (1991), and Rivera-Batiz (1988) scale economies are internal to firms; in Henderson (1974) and Eaton and Eckstein (1994) scale economies are external to firms. ${ }^{2}$ The mechanics of industry location in these models are relatively similar. The interaction of scale economies and transport costs creates a centripetal force, to use Krugman's language, that causes

\footnotetext{
3 In Henderson (1974) external cconomies are unspecified; in Eaton and Eckstein (1994) extemal econornies are due to spillovers in the cocumulation of human capital, as in Lucas (1988).
} 
firms to agglomerate in industry centers. With internal economies, firms economize on both transport costs and production costs by locating near a large market; with external economies, firms benefit from spillovers by locating near other firms in their industry. Land rents, or some other source of congestion costs, operate as a centrifugal force and work against agglomeration. To compensate workers for higher housing costs, higher commuting costs, or congestion-related disamenities in agglomerated regions, firms must pay workers relatively high wages. If centripetal forces dominate centrifugal forces firms agglomerate in one or more industry centers."

Where agglomerations form depends on a country's trading position with the rest of the world. Consider first the case of a closed economy. I use Mexico for illustrative purposes. Imagine Mexico as a line segment, with the United States located to the right of the segment (north) and Central America located to the left (south). Suppose labor is mobile along the line, but not across borders, and that land is immobile and uniformly distributed along the segrnent. Suppose also that, following the above logic, agglomeration economies cause firms to concentrate in industry centers, but land rents prevent the formation of a single massive city. Instead, a hierarchy of industry centers form. Figure 1 describes a spatial equilibrium in which rectangles represent the size and location of industry centers. A large industry center forms in the middle of the country, and centers of decreasing size form as one moves away from the middle towards the bonders. This spatial allocation of resources in qualitatively similar to that derived in Asilis

\footnotetext{
3 Other factors, of course, also contribnce to agglomeration. Site-specific natural resources may amract firms to certain locations. To the extent resource applies are fixed, they have no implications for growth and can be ignored in the andlysis that follows. Aliematively, a location may have amenities, such as nice beacbes or good weather, that autrect consumers, a in Robact (1982). Amenities need not be exogenous. Matsoyama and Takahashl (1993) model geographic concentration as the resolt of increasing retures in non-traded goods. Again, to the exient amenities are constant and lncreasing retoms are static, neither factor has implications for growth.
} 
and Rivera-Batiz (1993), Fujita (1988), Krugman (1994), and Rivera-Batiz (1988). It is by no means the only equilibrium, but it is an intuitively appealing one.

\section{Figure 1}

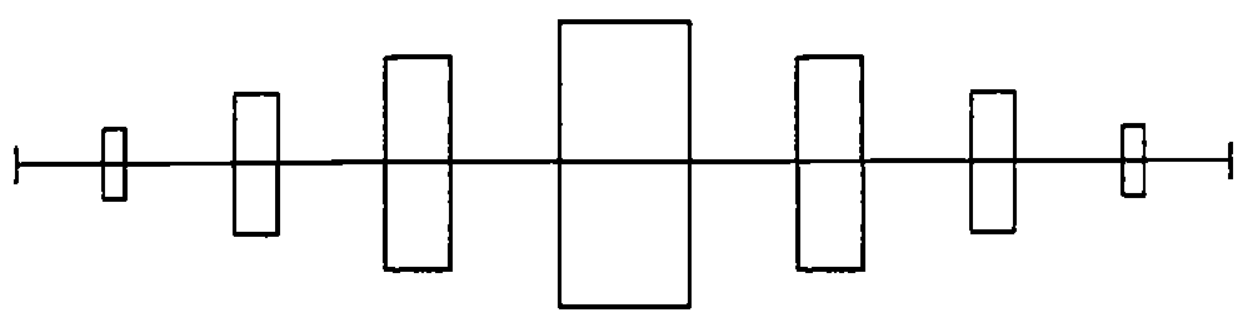

Central

America

Mexico

United

States

The composition of industry centers depends on the nanure of agglomeration economies (Henderson (1974)). With internal scale economies, agglomeration economies are pecuniary and the composition of industry centers is irrelevant what matters for firms is being near consumers; the fact industry centers also contain a large concentration of firms is not in and of itself an attraction. If agglomeration economies take the form of knowledge spillovers, or another nonpecuniary externality, the composition of industry centers reflects the manner in which firms benefit from proximity to one another. Within-industry and related-industry agglomeration economies create specialized concentrations of firms; agglomeration economies associated with industrial diversity create regional complexes with a wide array of activities.

Consider the effect of opening the economy to trade. The inportance of trade for industry location is that it expands the set of markets firms serve. Given the large size of the U.S. market relative to the Mexican and Central American markets, there is a premium on locations at the

- Strictly speaking, none of the models cited derives a hierarchy of industry centers as depicted in Figure 1 (see Fujin (1993)). Instead, there is a mass of activity in the center of the comntry that tails off in either direction. To derive the existence of distinct industry centers, a landscape with a discrete number of locations is generally imposed. 
right end of the line segment, near to the Mexico-U.S. "border.' To improve access to the U.S. market - that is, to reduce transport costs - firms bave an incentive to relocate their activities northwards. The existing pattern of agglomeration works as an opposing force: the local concentration of consumers and/or firms gives firms an incentive to remain where they are. Whether or not firms relocate depends on the relative strength of these two forces.

In the long run, if firms have a joint incentive to move, entire industry centers may relocate. Fixed moving costs operate as an initial barrier to relocation, but we can imagine a variety of mechanisms through which firms coordinate their actions. Rauch (1993a) models a sinuation in which developers use industrial parks to coordinate the relocation of entire industries in the presence of agglomeration economies. Ultimately, we expect the pattern of industry location to reflect the relative importance of Mexico's trading partners. Figure 2 gives one possible post-trade pattern of industry location, which is qualitatively similar to that derived by Krugman and Livas (1992). Agglomeration economies again imply the formation of a hierarchy of industry centers, now with the largest center located at the Mexico-U.S. border and industry centers decreasing in size as one moves south.

\section{Figure 2}

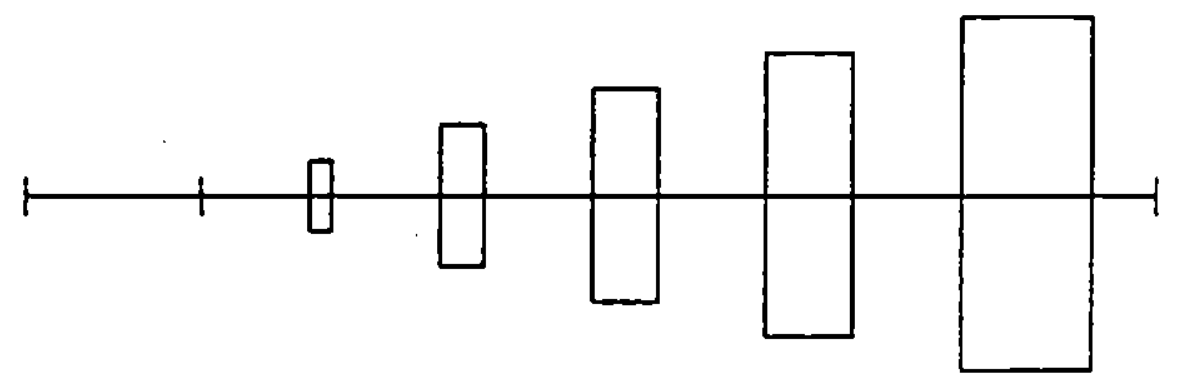

Central

United

America

Mexico

States 
The transition between the equilibrium in Figure 1 and the one in Figure 2 takes time, with the speed of adjustment depending on the nature of agglomeration economies. If agglomeration economies are pecuniary, the lure of the U.S. market may be sufficiently strong that firms move to the border as soon as they are able. In this case, adjustment to trade liberallzation is likely to be rapid. In the absence of spillovers, the only factors dissuading firms from relocating are fixed moving costs and the potential loss of local markets. The pull of the local market will be less significant if firms expect their neighbors to move to the U.S. border.

If agglomeraton economites take the form of knowledge spillovers, adjustment away from the closed-economy location pattern is likely to be more protracted. Trade makes proximity to the U.S. market more important, but it does not directly weaken the externality generated by a given level of agglomeration. Moreover, the sectoral reallocation of resources that trade brings may cause closed-economy industry centers to grow over the short or medium run. As specialization redirects labor from some industries to others, agglomeration economies make existing industry centers, all else equal, the ones most likely to benefit.

\section{B. An Empirical Model}

The preceding discussion suggests a simple empirical approach for studying how regional industries adjust to trade liberalization. To the extent transport costs to foreign markets affect firms' location decisions, we expect trade liberalization to cause a relocation of activities towards regions with relatively good access to the U.S. market. To the extent agglomeration economies matter, we expect large agglomerations of firms to grow relative to small ones.

I avoid the complications involved in long-ran adjustment to trade liberalization by 
focusing on the short run. ${ }^{3}$ The mobility of labor makes it relatively easy for firms to adjust regional employment levels in response to shocks." I study how trade liberalization affects regional-industrial employment by using a profit-function approach to estimate regional labor demand. For each industry assume there exists a well-defined profit function with the standard properties (Varian (1984)). ${ }^{7}$ Industries may be located in any number of states. For simplicity assume each state-industry produces goods for a single destination market (e.g., all goods pass through a central processing zone). Assume also there are positive transport costs that take Samuelson's ice-berg form: of each unit of output shipped from state $l$ to the central market only

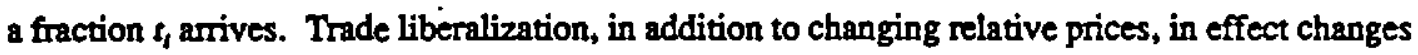
transport costs to the central market. By Hotelling's Lema, the dernand for labor in state $I$ by industry $j$ is given by

$$
L_{v}=-\frac{\delta \Pi_{\gamma}\left(R_{p}, t_{p} p_{p} \xi_{p}\right)}{\delta w_{y}}
$$

where $\Pi()$ is the profit function; $L_{q}$ is employment in state-industry $i j ; R_{j}$ is a vector of factor prices for $i j$, some of which vary across states and others of which do not, $p$, is the national price of industry $j$ s output $\xi_{j}$ is a vector of external effects; and $w_{j}$ is the wage.

A standard problem in empirically identifying agglomeration economies is that at any

S The problem with studying long-run adjustment is the existence of multiple equilibrin Theory offers liule gridance in determining which equilibris are more likely (see Krugman (1994)).

- To motivate the theory, I describe the adjustment process in terms of domestic firms deciding bow to edjust the location of their activities. It makes no difference for my puposes whecher the spatial reallocation of resources cecurs through existing firms relocating their operations or through the exit of old firms and the entry of new firms.

7 In event the profin function does not exist, the regression equation I specify still has an inierpretation as a generic employment growth equation. 
moment of time their effects are indistinguishable from those of unobserved fixed factors of production. I avoid this problems by studying the growth of regional labor demand: if agglomeration cconomies are dynamic in nature, they have implications for growth that are distinct from those of fixed factors." Taking logs, I assume I can reexpress (1) as

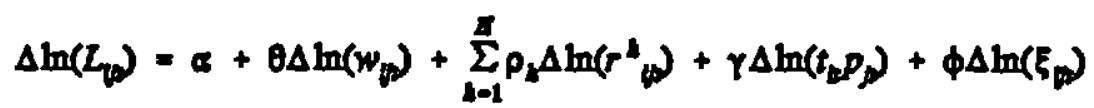

where $\Delta$ is the difference operator between time $t$ and time $t+l$ and the $r_{j}$ 's are non-labor factor prices. External effects are assumed to be positive in nature so that an increase in their magnitude increases labor demand for given factor and output prices. The dynamic agglomeration-economies hypothesis is that increases in external effects are a function of the initial concentration of resources in a given location:

$$
\Delta \ln \left(\xi_{\varphi}\right)=a+\sum_{l=1}^{L} b_{l} \ln \left(x_{\omega}^{b}\right)+c_{p}
$$

whero the $x_{w}$ 's measure the resource concentrations that generate externalities and $\varepsilon_{w}$ is an error term associated with the percentage change in external effects.

I consider three types of agglomeration economies: within-industry effects, where firms benefit from being near other firms in their industry; related-industry effects, where firms benefit from proximity to firms in upstream and downstream industries; and diversity effects, where firms benefit from proximity to firms in a wide array of industrial activities. Within-industry effects are the standard ones considered in the empirical literature (e.g., Cartton (1983), Nakamura (1985), Henderson (1986), and Glaeser et al. (1992)). Related-industry effects are generally

\footnotetext{
- That is, ixed factors affect the level of regional labor demand without affecting its growth.
} 
subsumed into within-industry effects or ignored altogether. I distinguish between within-industry externalities and related-industry externalities to control for the possibility that the benefits firms derive from proximity to their rivals differ from those they derive from proximity to their buyers and suppliers. The hypothesis that industrial diversity enhances growth relates to Jacobs' (1969) concept of the cross-fertilization of ideas between firms in different industries. The essence of Jacobs' story is that firms in one industry learn from firms in many industries. What enhances spillovers is not the agglomeration of firms in the same industry but the diversity of industries represented in a given location. In the growth of U.S. city industries, Glaeser et al. (1992) find evidence consistent with externalities related to diversity but not within-industry externalities.

Trade liberalization reallocates resources across sectors. To identify location-specific factors that affect regional-industry employment growth, I need to control for the sectoral effects of trade. I do so by rexpressing (2) in terms of deviations from national-industry changes. National-industry changes can be expressed as a function of industry weighted-average changes in factor prices, output prices, and external effects.' If labor is the only factor whose price varies across states, taking deviations from national-industry changes eliminates the output price and all non-labor factor prices from the expression. Equation (2) becomes

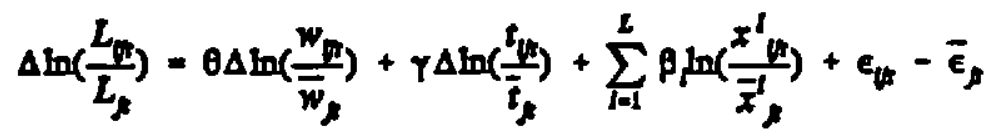

where

- To sec this note that $\Delta \lambda\left(x_{j}\right)=\xi_{\Delta} \Delta x_{n}$ in whicb case

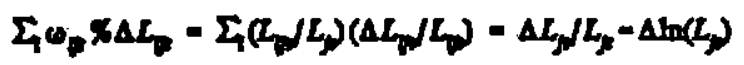

where $m_{1}=L_{4} L_{k}$ 


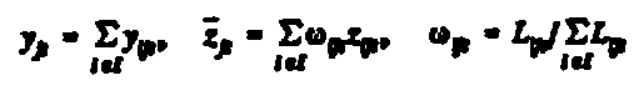

I use expression in (4) for estimation.

\section{The Data}

Data are drawn from the Mexico Industrial Census. The Census is a comprehensive survey of manufacturing establishments that provides periodic data on four-digit (ISIC) state industries. Mexico has 54 industries and 32 states. $^{10}$ I have collected data from the three most recent census years, 1980, 1985, and 1988. Mexico initiated its liberalization of trade in 1985. I have two sets of observations on changes in regional industry labor demand: from 1980 to 1985, the period preceding trade liberalization, and from 1985 to 1988, the period following the initiation of trade reform. It would be desirable to have a year later than 1988 , but more recent census data are not yet available. The swiftness with which liberalization was enacted suggests the initial effects of trade reform should be observable by 1988 .

\section{A. The Liberalization of Trade}

Mexico's economy was largely closed to trade from the 1950's until the mid 1980 's. The government initiated a conscious policy of trade protection in the late 1940 's when it raised tariffs and instituted a system of import licenses (King (1970)). Successive administrations expanded trade barriers, mainly by increasing the range of goods covered by import licenses. Trade

\footnotetext{
20 There are numerons versions of the ISIC (International Standard Industrial Classification) code. The Mexico Census purports to use the United Nations Revision 2 ISIC. There are, however. subtle differences between the UN version and the Mexican version (the UN version, for instance, has more than 54 four-digit industries).
} 
barriers biased firms towards production for the domestic market. Not only were firms protected from foreign competition, but they were at a relative disadvantage in foreign markets due to the fact that they had to pay artificially bigh prices for imported inputs. The government also used export controls to direct production towards the domestic market." Periodic overvaluation of the exchange rate was an additional incentive against exporting.

The government decided to open the economy to trade in 1985 and announced plans to join the General Agreement on Trade and Tariffs (GATT). There was initial skepticism over the seriousness of the government's reformist intentions, due in part to failed liberalization attempts in the late 1970's and early 1980's. The govenment moved swiftly, however, drastically lowering most trade barriers within three years. In mid 1985, the national average tariff was 23.5 percent, and import-license requirements covered 92.2 percent of national production. By Decernber 1987. import-license coverage had been reduced to 25.4 percent of national production and the average tariff had been reduced to 11.8 percent, with a maximum rate of 20 percent. Concomitant to reform the government abolished export controls and devalued the nominal exchange rate.

Table 1 shows annual weighted-average tariffs and import-license coverage by two-digit (ISIC) industry for the period 1984-1990. In 1985, the average tariff ranged from 13.6 percent in non-metallic minerals to 47.3 percent in wood products; import licenses were required for over 85.0 percent of products in all two-digit industries. The government first cut import-license requirements, reducing average import-license coverage to below ten percent by 1987 in all industries except food products, texilles, and metal products. The government then began to reduce tariffs; by 1988, the maximum tariff rate in any industry was in other industries (toys.

II In 1980, Mexico had export controls on 85 percent of non-oil exports (Secretariat of Trade and Indestrial Promotion, unpublished dam). 
instruments, jewelry) at $\mathbf{1 7 . 1}$ percent. The only industry that continnes to enjoy relatively high rates of protection is metal products, due mainly to import restrictions on autos.

\section{B. Regional Employment in Mexico}

Trade liberalization has coincided with a sectoral and spatial reorganization of employment in Mexico. Table 2 shows the average annual change in national employment by two-digit industry for the periods 1980-1985 and 1985-1988. ${ }^{2}$ In the period before trade liberalization, manufacturing exployment grew at an average annual rate of 3.34 percent, in the following period, manufacturing employment declined in absolute terms at an average annual rate of 0.75 percent. The post-trade employment decline was concentrated in chemicals and basic metals, which declined at annual average rates of 7.40 percent and 8.78 percent, respectively.

It is difficult to detect the effects of trade liberalization in national level employment changes. Trade reform was not the only shock to the Mexican economy in the 1980 's. The country experienced a severe macroeconomic contraction in 1986 and 1987, as the government imposed austerity measures to stabilize the economy. Changes in regional employment offer useful clues for identifying the effects of trade reform. Holding industrial composition constant, Mexico's regions are subject to the same macroeconomic shocks. ${ }^{13}$ Studying regional-industry exployment growth relative to national-industry employment growth sweeps out the effects of

12 Average annual employment grownt is calculated as the change in log employment divided by the time interval in years between observations.

is It is possible Mexico's macroeconomic shocks varied ecross regions, but it does not seem likely. Mexico's stabilizacion measures included drastle cuts in governmene spending and a peso devalnation. The largest cuts in outlys came in consumption subsidies. Pablic spending is under centralized control. The federal governiment collects tax revenoes from the states and determines bow they will be disbursed. I am aware of no evidence which indicates the government favored individual states in making spending cuts. 
economy-wide shocks and leaves the regional effects of trade reform.

Figure 3 plots average annual relative ecoployment growth for state-industries in the periods 1985-1988 and 1980-1985. ${ }^{14}$ Average annual relative employment growth is defined as the annualized change in log employment for the state industry minus the annualized change in log exployment for the national industry (Table 5 gives variable definitions). The line in Figure 3 is a regression given by the following equation:

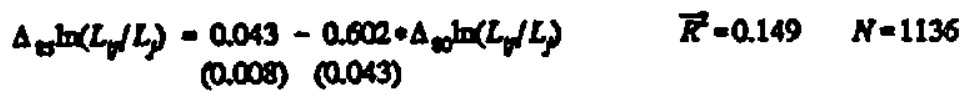

where $\Delta_{e 0}$ indicates the average annual change over 1980-85, $\Delta_{6 s}$ indicates the average annual change over 1985-88, $L_{j}$ is employment in state-industry $i, L_{j}$ is national employment in industry $j$, and standard errors are in parentheses. While most state industries had zero relative employment growth in both periods, the statistically significant (at the .05 level) negarive slope of the regression line indicates many state industries had positive relative growth in the first period and negative relative growth in the second period, or vice-versa. This is consistent with the idea that the pattern of state-industry employment growth before trade reform differed from that after trade reform.

To identify broad patterns in state-industry employment growth, it is useful to summarize comployment changes at the regional level. I group states into five regions running north to south (see Figure 4): (1) the Border, which contains states that border the United States; (2) the North. which contains the next tier of northern states; (3) the Center, which contains states surrounding

14 The points in Figure 3 are abbreviated stace names (see Figure 4). 
Mexico City; (4) Mexico City, which conains the two states the capital occupies; ${ }^{\text {L3 }}$ and (5) the South, which contains all states south of the capital.

Table 3 shows regional shares of national employment by two-digit industry for 1980 and 1988. There are three striking features about regional employment in Mexico. The first is the overall geographic concentration of manufacturing. Under the closed economy, the central states, and Mexico City in particular, were Mexico's manufacturing belt. In 1980, the Mexico City region contained 44.4 percent of national manufacturing employment, and the Center contained 25.5 percent. Hanson (1994) shows this pattern of industry location had existed since 1960.

The second striking feature of the data is the variation in geographic concentration acsoss industries. In 1980, employment in food products and non-metallic minerals was spread relatively evenly across regions. These industries include goods, such as bread, tortillas, and cement, that are not traded over long distances, hence their location reflects the regional distribution of population. There are other industries that are highly concentrated geographically. In textiles and apparel, paper and printing, chemicals, metal products, and other industries, over 75 percent of employment is concentrated in just two regions. These industries are relatively footloose, in that production is relatively intensive in the use of relatively mobile factors. High levels of agglomeration in footloose industries is consistent with some sort of scale economies.

The third fearure of the data is that over the 1980's there was a dramatic shift in relative employment from Mexico City to the Border. Between 1980 and 1988, the Mexico City region's share of manufacturing employment fell from 44.4 percent to 33.2 percent, while the Border

is The Mexico City metropolitan area encompasses the Federal District and several communities in the state of Mexico. Though the geographical area the capital occupies in the state of Mexico is small, it contains the vast majority of the state's manufacturing activity. 
region's share increased from 21.0 percent to 28.2 percent. The overall regional employment shift was not uniform across industries. Table 4 shows relative employment growth by region and two-digit industry for the periods 1980-1985 and 1985-1988. From 1985 to 1988, the Border had manufacturing employment growth relative to the nation as a whole of 6.53 percent. This growth varied widely across individual industries, ranging from 11.74 percent in textiles and apparel, 9.77 percent in metal products, and 9.99 percent in other industries, to -0.63 percent in food products and -0.28 percent in besic metals. Similarly, after 1985 overall manufacturing employment growth in the Center relative to the nation as a whole was -2.82 percent, but the region enjoyed relative employment growth of 5.55 percent in wood products and 2.62 percent in other industries. Just as the Border was not uniformly attractive to all industries, the Center was not uniformly repellent to all industries.

The northward shift in employment after 1985 is consistent with the transport-costs hypothesis that, in response to trade liberalization, firms shift their operations to locations with relatively good access to forcign markets. Location, however, does not tell the whole story. The geographic concentration of industry prior to trade reform is consistent with agglomeration economies. The heterogeneity in regional-industry response to trade suggests that locationspecific factors other than proximity to the United States play an important role in explaining how regional industries adjust to trade. Summary statistics are insufficient to determine if agglomaration economies are among these factors.

\section{Results on Regional Adjustment to Trade Liberalization}

If location-specific factors such as agglomeration and distance to foreign markets matter 
for adjustment to trade liberalization, then the most direct way to identify these effects is to study the growth of the same industries in different locations and verify in which locations industry employment grows faster. The unit of analysis is the four-digit state-industry. I study changes in state-industry employment during the periods 1980-1985 and 1985-1988. Observations on relative employment growth in $1980-1985$ serve as a control group for identifying the locationspecific factors that affect adjustment to trade liberalization. There are $1,728(32 \times 54)$ potential observations per time period, but not all industries are present in all locations. I have 1,205 observations for 1980-1985 and 1,247 observations for 1985-1988. I impose a simple criterion to eliminate observations that are likely subject to extreme measurement error, which reduces the observations to 1,151 for $1980-1985$ and 1,116 for $1985-1988 . .^{16}$

\section{A. Variable Definition}

Table 5 gives variable definitions and Table 6 gives variable means and standard errors for each time period. The dependent variable is average annual relative employment growth. That there was positive relative exoployment growth on average in both periods reflects the fact that in each industry a few locations (e.g., Mexico City) lost a lot of employment while a large number of industries gained some exployment.

Following equation (4), I specify relative employment growth as a function of initial conditions in the state industry relative to the national industry,

\footnotetext{
10 Tho restrictions I impose are (1) industry employment is positive in the initial period, (2) industry exployment remains positive after subtracting out non-remmerated workers (mainly fanily labor), and (3) positive wages are paid to employees.
} 


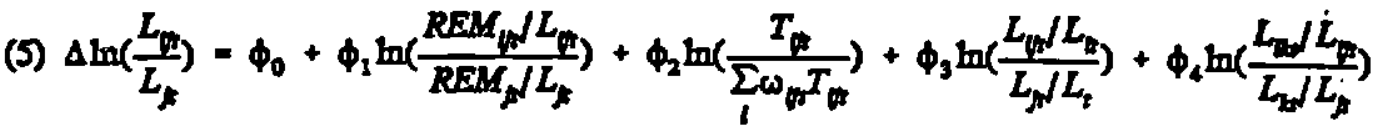

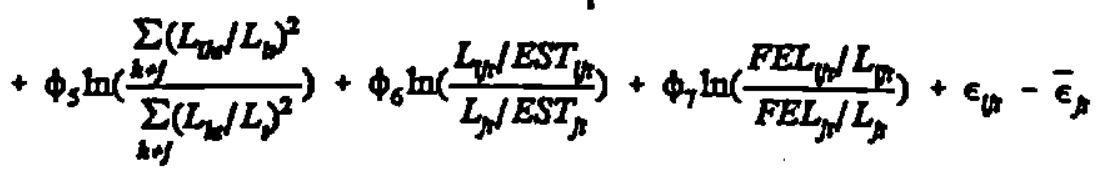

where $i$ indexes the state, $j$ indexes the four-digit industry, $k$ indexes the two-digit industry to which $f$ belongs, and $t$ indexes the initial period. The first term in equation (5) is the stateindustry wage relative to the national-industry wage. I measure the wage as annual remuneration per worker (REMIL). I use the relative wage in the initial period, rather than the change in the relative wage, to avoid introducing simultaneity into the regression. From Table 6, the stateindustry wage was on average about half the national-industry wage, which indicates a high degree of wage dispersion. To the extent wages reflect market conditions, I expect relative employment growth to be decreasing in the relative wage. ${ }^{17}$

The second term in (5) represents the change in transport costs. Prior to trade liberalization, transport costs change relatively little across periods. ${ }^{12}$ In the transition from a closed to an open economy the change in transport costs reflects the inclusion of foreign consumers as a source of demand. A reasonable proxy for transport costs to foreign markets is distance to the United States, which I measure as road distance in leilometers from the state

n The Mexican government sets minimum wages by region and by industry. Mexican labor law mandates a host of benefits and standards, including the right to union representation, paid vacations, employer-paid health care. profit sharing, and semi-annusal bonuses of a specified amount.

in Over long periods, transpont costs change a great deal, as roads and transportation technology improve, but it is milikely such developments significantly alter transport costs over horizons as short as three of five years. 
capital to the nearest major border crossing $(T)$. 19 The distance measure I use is state distance to the United States $\left(T_{1}\right)$ relative to industry weighted-average distance to the United States $\left(\Sigma_{i} \omega_{i} T\right)$. Prior to trade liberalization, there is no reason transport costs to the United States should affect labor demand; hence, I expect no relation between relative distance to the United States and relative employment growth for 1980-1985. If transport costs to foreign markets matter for industry location after trade liberalization, relative distance to the United States will be negatively related with ermployment growth for 1985-1988.

The third through fifth terms in (5) represent growth in external effects, which by hypothesis is a function of initial levels of industry agglomeration. The first source of externalities I consider is within-industry agglomeration, which I measure as the share of state ermployment in the industry $\left(L_{V} / L_{\downarrow}\right)$ relative to the share of national employment in the industry $\left(L_{j} / L\right)$. Glaeser et al (1992) describe this as a measure of specialization as it controls for simations where the state-industry is large purely because the state is large. If within-industry externalities are positive, I expect relative employment growth to be higher where within-industry agglomeration is higher.

The second source of externalities is related-industry agglomeration. I define related industries as those that share a given industry's two-digit classification. The two-digit classification tends to combine industries that share direct buyer/supplier relationships or that produce goods for similar markets. In apparel (ISIC 3220), for instance, my measure of related industries includes textiles (ISIC 3213), knitwear (3214), leather (3230), and footwear (3240).

\footnotetext{
1) The major border crossings are Tijuana-San Diego, Nogales, Ciudad Jutrez-El Paso, and Nuevo LaredoLiredo. Using dfsance to messure transport costs is equivalent to essuming that land transport is the only available means of ferying goods. Firms of course have the alternative of shipping goods by sea or by air. I deal with such issoes indirectly by incloding fixed state effects in the regression.
} 
These industries are close to apparel in product space, and hence are likely to use similar production and/or distribution technologies. Technological commonalities create opportunities for firms to learn from one another. My measure of related-industry agglomeration is two-digit state employment relative to four-digit state employment $\left(L_{\alpha} / L_{p 2}\right)$, adjusted by two-digit national employment relative to four-digit national employment $\left(L_{\downarrow} / L_{\mu}\right)$. If related-industry externalities are positive, I expect relative employment growth to be higher where related-industry agglomeration is higher.

The thind source of externalities is industrial diversity. I measure diversity for a stateindustry as the sum of squared state employment shares for all other industries in the state $\left(\Sigma_{m}\left(L_{g} / L_{L} J^{2}\right)\right.$, relative to the sum of squared national employment shares for all other industries in the nation $\left(\Sigma_{m}\left(L_{N} / L J^{2}\right)\right.$. The more even is the distribution of state (national) employment across industries, the larger is the sum of squared state (national) employment shares. The larger is the ratio of the sum of squared state employment shares to the sum of squared national employment shares the more diverse is the state relative to the nation as a whole. If industrial diversity generates positive externalities, relative employment growth will be higher where relative diversity is higher.

The sixth and seventh terms in (5) represent other factors that affect relative employment growth. Not all firms in an industry necessarily use the same technology or operate at the same level of efficiency. To control for such differences, I include the log of the average establishment size in the state industry relative to the weighted-average establishment size in the industry as a whole, where I measure establishment size as workers per establishment (LIEST). While large relative size may indicate better technology or imperfect competition, it may also indicate active 
unions that force firms to operate at relatively high employment levels.

Prior to trade liberalization, Mexico allowed off-shore in-bond assembly plants, known as maquiladoras, to operate in special enterprise zones along the Mexico-U.S. border. Maquiladoras assemble imported inputs for export. They are exempted from all import restrictions, as long as they export all of their output. Maquiladoras hire a large share of women relative to other manufacturing establishments (Wilson (1992)). ${ }^{20}$ The presence of maquiladoras along the border may have created regional differences in labor-force composition. To control for this possibility, I include the share of employment that is female in the state-industry $\left(F E L_{\sigma} / L_{V_{0}}\right)$ relative to share of employment that is female in the national industry $\left(F E L_{j} / L_{\gamma}\right)$.

\section{B. Estimatlon Issues}

I have observations across states, industries, and ime. I control for the possibility there are idiosyncratic components to state-industry employment growth by allowing the error term $\varepsilon_{p}$ in (5) to have the following structure:

$$
c_{p}=r_{1}+H_{j}+\nu_{p}+\eta_{0}
$$

where $x_{i}$ is a fixed state effect, $\mu_{j}$ is a fixed industry effect, $v$, is a fixed year effect, and $\eta_{\bar{y}}$ is an i.i.d random variable with mean zero and variance $\sigma$. The alternative to fixed effects is random effects. Random-effects estimation imposes the assumption that the elements of $\varepsilon_{v ;}$ are uncorrelated across states, industries, and years. Recall that not all industries are present in all states. The unbalanced panel is due not to a lack of data on these industries but to an equilibrium

\footnotetext{
Indeed, assembly plants are the vehicle through which many women enter Mexico's mannfacturing labor force.
} 
process that allocates industries across states. That a given industry has zero employment in a state reflects the combined idiosyncratic characteristics of the state and the industry, which implies there is little basis for assuming that state effects and industry effects are uncorrelated. In this case, fixed-effects estimation is the more prudent approach.

The regression equation I estimate has the structure of (4), in which I have in effect taken deviations from industry weighted averages. Taking weighted-average deviations creates an error term with the following structure:

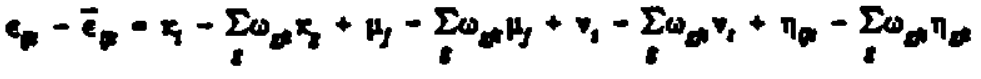

$$
\begin{aligned}
& -x_{1}-\sum_{0}+x^{2}+\eta_{0}-\sum_{0}+\eta_{4}
\end{aligned}
$$

where $\omega_{0}$ is state-industry ijs share of national-industry is employment. Taking deviations eliminates industry and year effects, but leaves state effects and a random error term which has zero mean but is no longer spherical. ${ }^{21}$ The second right-hand-side term in (7) varies across industries if relative state employment shares vary across industries (which we know from the last section is true), introducing a new industry effect into the regression.

One approach is to take deviations from state and industry means, which would eliminate all fixed effects. The problem with this is that two my regriessors, relative transport costs and relative industrial diversity, vary little across industries within a state. Taking deviations from state means would virtually eliminate these variables from the regression. Instead, I estimate the model in the form of equation (5), and I run each regression twice, first without controlling for fixed effects and then including state and industry dummy variables. Given the large number of

$n$. The random error term $\eta_{\mu}-\Sigma_{f} \omega_{e,} \eta_{d k}$ has mean zero and variance $\sigma^{2}\left(l-\Sigma_{f} \omega_{\alpha}{ }^{2}\right)$. The variance differs across industries if the sum of squared state employment shares differs across industries. 
observations in the sample, using dummy variables to control for fixed effects does not substantially reduce the degrees of freedom of the regression. I use White's correction to obtain beteroskedasticity-consistent standard errors. ${ }^{2}$

\section{Estimatlon Resuits}

\section{C.1 The Pre-Reform Period (1980-1985)}

Table 7 gives estimation results on relative employment growth for 1,151 observations during the period 1980-1985. The regressions reported in the (a) columns do not include state and industry dummies; those in the (b) columns do. Among the control variables, the relative wage and the relative size of the fermale labor force are unrelated with relative employment growth. Relative employment growth is lower where relative establishment size is higher, in eight of the twelve regressions the variable is negative and significant at the .05 level. This is consistent with the idea that locations with relatively large firms are either the targets of union organizing activity or its recent victims.

The most interesting results are for the agglomeration and distance variables. As expected, prior to trade liberalization relative distance to the United States is unrelated with relative employment growth. The coefficient on the variable is insignificant at the .05 level in three of four regressions; where it is significant, it is positive. Distance to foreign markets does not affect regional labor demand when firms produce for domestic markets.

Spillovers between firms in the same industry do not appear to enhance growth. Relative employment growth is lower where within-industry agglomeration is higher, the variable is

2 While I have prior information on the manner in which the vartance is likely to differ across indestries, this may not be the only source of beteroskedasticity in the regression. The White correction is a general treatment. 
negative and significant at the .05 level in all regressions. The quantitative effect is not large. From the results in column (6.b), a one standard deviation increase in within-industry agglomeration (1.260) reduces annual average relative employment growth by 2.80 percent, or one-eighth a standard deviation.

Other types of agglomeration effects are positively related with growth. Relative employment growth is higher where related-industry agglomeration is higher, the variable is positive and significant at the .01 level in all regressions. The quantitative effect is moderate. From the results in column (6.b), a one standard deviation increase in related-industry agglomeration (1.110) increases average annual relative employment growth by 4.72 percent, or one-fourth a standand deviation. Industrial diversity is unrelated with relative employment growth; the variable is significant in only one regression and in that case it is negative.

The results for relative employment growth during 1980-1985 suggest Mexico was undergoing a spatial reallocation of employment even before trade liberalization. One explanation is that firms anticipated trade reform and began to relocate their activities prior to its actual initiation. This is inconsistent, however, with the fact that state industries close to the United States did not grow more rapidly than other states. An alternative explanation is that Mexico's manufacturing belt was beginning to sag under its own weight. The cities in the manufacturing belt, and Mexico City in particular, grew to enormous size between 1950 and 1980 . As in the post-war United States, congestion costs and union militancy may have encouraged firms to move their activities ont of established manufacturing regions. This is consistent with the fact that relative establishment size is negatively related with growth. The results on related-industry agglomeration suggest that while large industry centers in Mexico's manufacturing hearland were 
breaking apart, broadly specialized regional industrial complexes were developing elsewhere.

\section{C.2 The Post-Reform Period (1985-1988)}

Table 8 gives estimation results for 1,116 observations during the period 1985-1988. The most striking change from the results for $1980-1985$ is that, as expected, relative employment growth is lower in state-industries that are relatively distant from the United States; the variable is negative and significant at the .05 level in three of four regressions. ${ }^{23}$ This is consistent with the hypothesis that with the opening of the Mexican economy firms have begun to shift their activities towards the Mexico-U.S. border, where they enjoy relatively low-cost access to the U.S. market. The quantitative effect of distance is not large, however. From the results in column (6.b), a one standard deviation increase in relative distance (1.344) reduces average annual relative employment growth by 3.10 percent, which is one-ninth a standard deviation.

There no longer appears to be a negative relation between within-industry agglomeration and growth; the coefficient on the variable is negative and significant in only one of four regressions. It remains true that relative employment growth is higher where related-industry agglomeration is higher, the coefficient on the variable is positive and significant at the .01 level in all regressions. The findings remain consistent with the idea that Mexico is developing broadly specialized regional industrial centers. The results on distance suggest the most favored industry centers are those relatively close to the United States.

Another change from the previous results is that relative employment growth is bigher

\footnotetext{
D As was mentioned earlier, relative distance does not vary greatly across indusuries within a state. This implies there is multicollinearity between relative distance and state dummy variables It is not surprising, then, that when state dummies are incloded in the regression the coefficient on relative distance is not always significant.
} 
where the relative size of the female labor force is higher, the variable is positive and significant at the .01 level in all regressions. This is consistent with the idea that since trade reform Mexican firms are converting to assembly-type activities, which are relatively intensive in the use of female labor. As before, the relative wage and relative industrial diversity are unrelated with growth. The results on relative establishment size are more consistent than in the previous sample; the coefficient is negative and significant at the .01 level in all regressions.

Comparing Tables 7 and 8, it appears that after trade liberalization there was a structural break in the pattern of regional labor demand, which would be consistent with the theories presented in section two. To formally test this hypothesis, I combine observations from the two samples and reestimate the regression. If trade liberalization has indeed caused a structural break, the regression coefficients on the period after 1985 will differ from those before 1985 . Table 9 shows results from pooled regressions. ${ }^{24}$ In all regressions I reject the hypothesis that regression coefficients are the same in both periods at the .01 level. The results on individual coefficients confirm the preceding results: after 1985, the negative effect of relative distance to the U.S. is larger, the positive effect of the female share of the labor force is larger, and the negative effect of relative establishment size is larger.

\section{C.3 Sensitivity Analysis}

To check the robustness of my findings, I re-estimate the regression equation, imposing a number of restrictions on the sample. One possibility is that the results are driven by the decomposition of the Mexico City manufacturing belt, and that in outlying regions the

* year85 is a dummy variable that bles a value of one if the year is 1985 (the altemative being 1980). 
agglomeration and distance effects evident in Tables 7-9 do not exist. To verify this is not the case, I drop state industries in the Mexico City region from the sample, which in the pooled sample reduces the number of observations from 2,267 to 2,080 . Table 10 gives the results. Coefficient magnitudes and patterns of significance are virtually identical to those in the corresponding columns of Table 9.

A second possibility is that the results are driven by regional variation in adjustment to Mexico's stabilization policies in the late 1980 's. Real GDP in Mexico fell by 4.36 percent in 1986, and rose by 1.92 percent in 1987 and 4.10 percent in 1988 . Due to the presence of the maquiladora industry, states along the Mexico-U.S. border, where special enterprise zones where concentrated, wero oriented towards export production before trade liberalization. Producers in interior states may have suffered a large fall in demand for their goods relative to border producers during the period 1985-1988 due to the fact that they were primarily oriented towards production for the domestic market. What appears to be a northern shift in regional labor demand after trade reform may only have been the uneven effects of Mexico's stabilization policies. To verify this is not the case, I drop industries in the Border region from the sample, which in the pooled sample reduces the number of observations from 2,267 to 1,823 . Table 11 gives the results. Again, coefficient magnitudes and pattems of significance are virtually identical to those in the corresponding columns of Table 9.

So far, I have pooled all industries together. This imposes the assumption that distance and agglomeration matter equally for all industries. Casual observation suggests this is not the case. Some industries produce goods that are not widely traded across regions or that are intensive in the use of relatively immobile inputs. Dropping these industries from the regression 
should only strengthen the results. The industries I exclude are food products (ISIC 31), paper and printing (ISIC 34), non-metallic minerals (ISIC 36), and basic metals (ISIC 37). Many food products, such as bread, beverages, and meat, are perishable or have low value-to-weight ratios and therefore costly to transport. Firms that produce these goods tend to locate near large population centers. The production of paper, non-metallic minerals, and basic metals is relatively intensive in the use of inputs with relatively high transport costs. The remaining industries textiles and apparel, wood products, chemicals, metal products, and other industries - are relatively intensive in the use of relatively mobile resources. Table 12 gives the results. Dropping the four industries reduces the number of observations in the pooled sample from 2,267 to 1,334 . Again, the results are virtually identical to those in Table 9.25

\section{Discussion}

The empirical results describe the general features of the post-trade pattern of industry location that is emerging in Mexico. Since trade reform, there has been an overall northward shift in the location of manufacturing activities. Mexico's closed-economy manufacturing belt is breaking apart, or at least diminishing in relative importance, as firms relocate their activities to regions with better access to the U.S. market. The implementation of the North American Free Trade Agreement will further improve Mexico's access to the U.S. market, which is likely to reinforce firms' motivation to be near the United States.

Accompanying industry relocation is a change in the composition of Mexico's industry

\footnotetext{
y In a separtio set of regresions, whose results I do not repon in the paper, I allow the coefficient on relative distance to vary across two-digit industriet. For both 1980-1985 and 1985-1988. I fail to reject the hypothesis that distance effects are constant coross industries at the .05 level.
} 
centers. The expirical results are consistent with the hypothesis that broadly specialized regional incustrial centers are replacing the dense concentrations of industries that dominated the Mexican landscape under the closed economy. The shift involves both a spatial decentralization of employment and a lessening of regional specialization. The fact that agglomeration is positively related with growth is consistent with the existence of nonpecuniary agglomeration economies. It appears the breakup of the Mexico City manufacturing belt was underway before 1985, and hence cannot be entirely atributed to trade liberalization. Changes in tax policy, transport costs, union-organizing activities, and cumulative congestion effects are all candidate explanations.

\section{Concluding Remarks}

This paper studies the regional effects of trade liberalization. I focus on the opposing forces of transport costs, which encourage firms to relocate to regions with relatively good access to foreign markets, and agglomeration economies, which encourage the growth of closed-economy industry centers. The particular case I consider is state-industry employment growth in Mexico before and after trade reform. Consistent with the transport-costs hypothesis, employment growth after trade reform is higher in regions that are relatively close to the United States, which is the major foreign market for Mexican producers. Certain types of agglomeration matter for growth. Employment growth is higher in state-industries with large agglomerations of firms in upstream and downstream industries; the agglomeration of firms in the same industry is negatively related with growth. Together, the results describe the decomposition of the Mexico City manufacturing belt and the creation of smaller, broadly specialized industry centers in Mexico's north.

In the last fifteen years, there have been dozens of episodes of trade liberalization in the 
developing world and the formerly communist countries. The regional effects of reform have received scant attention. My results suggest that regions differ greatly in the manner in which they adjust to trade. Industry relocation creates additional adjuswnent costs that policy makers often ignore in planning how to accommodate the opening of the economy. More generally, my results support the idea that with economic integration national identities are descendent and regional identities are ascendent. As NAFTA further integrates Mexico into the North American economy, the ties between northern Mexico and the southwestern United States will strengthen and those between northern and southern Mexico will weaken. In such a world it increasingly makes sense to make regions, rather than nations, the unit of analysis in international trade. 


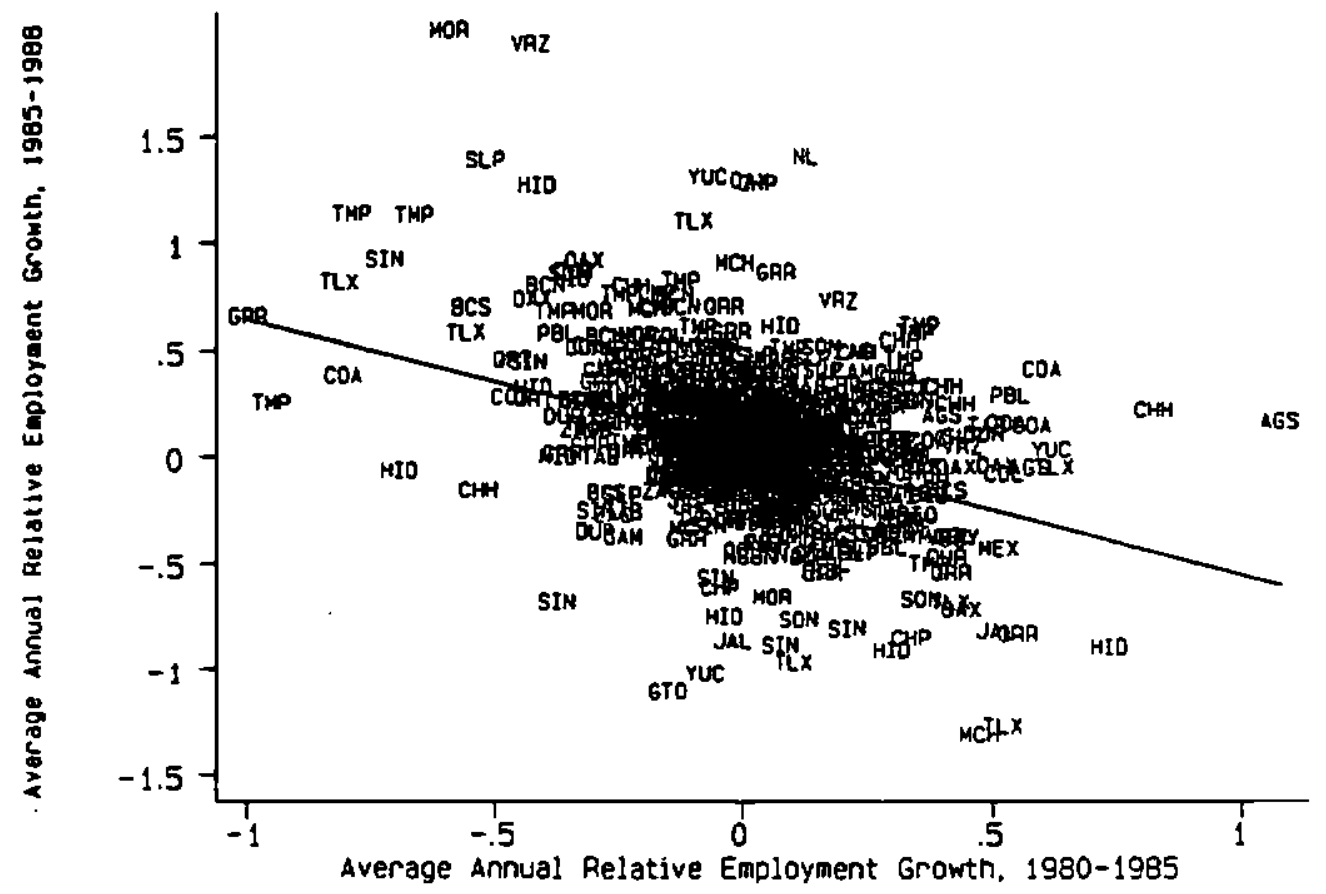

Figure 3 


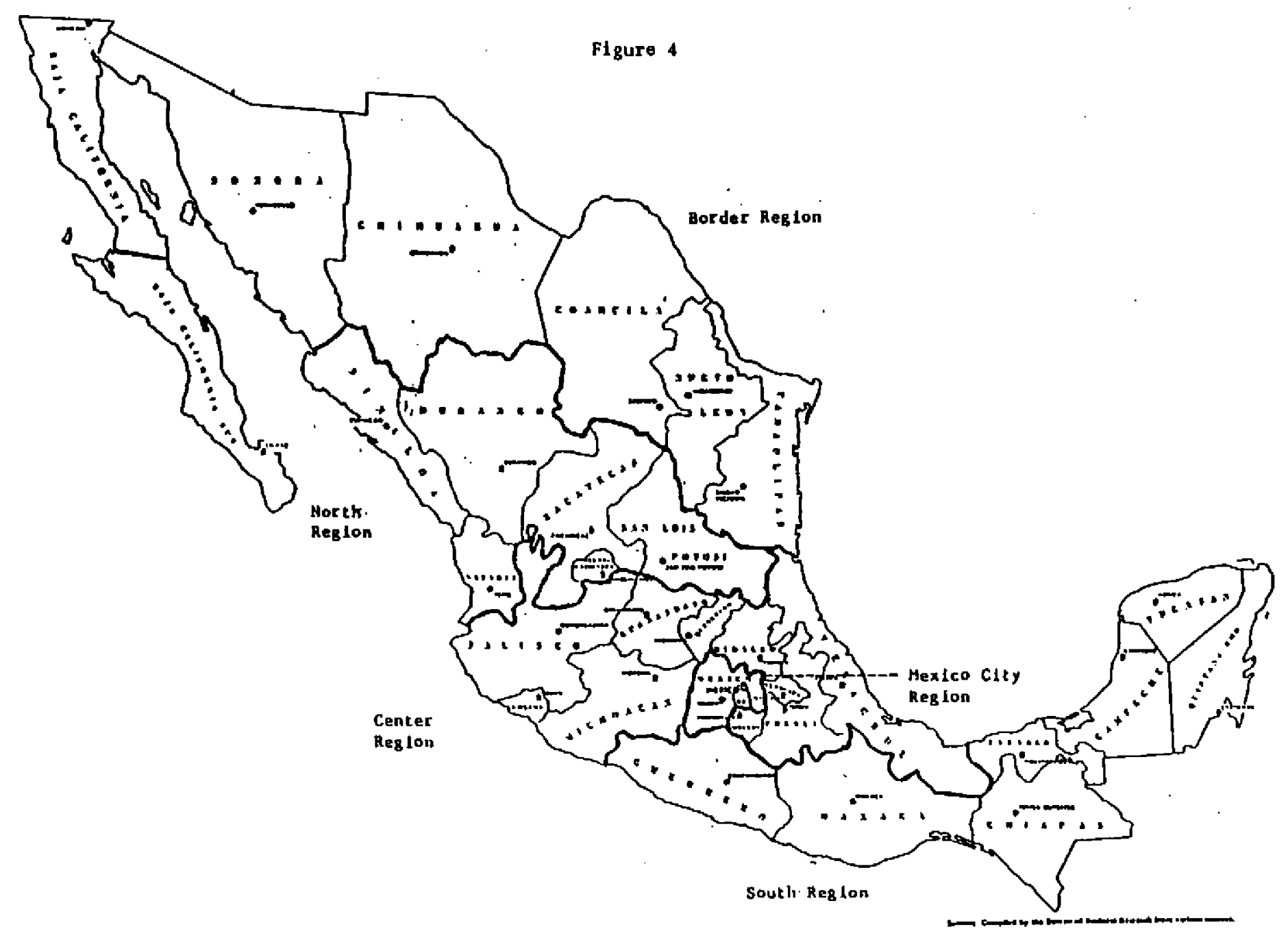




\section{References}

Asilis, C and L. Rivera-Batiz. 1993. "Geography, Trade Patterns, and Economic Policy," mancscript, International Monetary Fund and University of Florida.

Blanchard, O. and L. Katz. 1992. "Regional Evolutions." Brookings Papers on Economic Activity 1: 1992, 1-75.

Cartion, D.W. 1983. "The Location and Employment Choices of New Firms." Review of Economics and Statistics 65: 440-449.

Eaton, J. and Z Eckstein. 1994. "Cities and Growth: Theory and Evidence from France and Japan." NBER Working Paper No. 4612.

Fujita, M. 1988. "Monopolistic Competition and Urban Systems." European Economic Review 37: $308-15$.

Fujita, M. 1993. "Monopolistic Competition and Urban Systems." European Economic Review 37: 308-15.

Garza, G. 1985. El Proceso de Industrialización en la Ciudad de MExico, 1821-1970. Mexico City: El Colegio de Mérico.

Glaeser, E., H. Kallal, J. Sheinkman, and A. Shleifer. 1992. "Growth in Cities." Journal of Political Economy 100: 1126-1152.

Grossman, G. and E. Helpman. 1991. Innovation and Growth in the Global Economy. Cambridge: MIT Press.

Hanson, G. 1994. "Increasing Returns and the Regional Structure of Wages." Manuscript, University of Texas.

Henderson, J.V. 1974. "The Sizes and Types of Cities." American Economic Review 64: 640656.

Henderson, J.V. 1986. "Efficiency of Resource Usage and City Size." Journal of Urban Economics 19: 47-70.

Instituto Nacional de Estadistica, Geographra e Informática (INEGD. XI Censo Industrial, (1981). XII Censo Industrial, (1985). Mexico City: INEGL Resultados Oportunos, (1989). Aguascalientes: INEGI.

Jacobs, J. 1969. The Economy of Cities. New York: Vintage. 
Jaffe, A., M. Trajtenberg, and R. Henderson. 1993. "Geographic Localization of Knowledge Spillovers as Evidenced by Patent Citations." Quarterly Journal of Economics 108: 577-598.

King, T. 1970. Mexico: Industrialization and Trade Policies Since 1940. London: Oxford University Press.

Krugman, P. 1991. "Increasing Returns and Economic Geography." Journal of Political Economy 99: 483-499.

Krugman, P. 1994. "Fluctuations, Instability, and Agglomeration." NBER Working Paper No. 4616.

Krugman, P. and R Livas. 1992. "Trade Policy and the Third World Metropolis." NBER Working Paper No. 4238.

Lucas, RE. 1988. "On the Mechanics of Economic Development" Journal of Monetary Economics 22: 3-42.

Matsuyama, K and T. Takahashi. 1993. Self-Defeating Regional Concentration. Manuscriph. Northwestem University.

Nakamura, R 1985. "Agglomeration Economies in Urban Manufacturing Industries: A Case of Japanese Cities." Journal of Urban Economics 17: 108-24.

Porter, M. 1990. The Competitive Advantage of Nations. New York: The Free Press.

Rauch, J. 1990. "Comparative Advantage, Geographic Advantage, and the Volume of Trade." NBER Working Paper No. 3512.

Rauch, J. 1993a. "Does History Matter Only When It Matters a Little?" Quarterly Journal of Economics 107: 843-867.

Rauch, J. 1993b. "Productivity Gains from Geographic Concentration of Human Capital: Evidence from the Cities." Journal of Urban Economics, forthcoming.

Rivera-Batiz, FL. 1988. "Increasing Returns, Monopolistic Competition, and Agglomeration Economies in Consumption and Production." Regional Science and Urban Economics 18: 12553.

Rivera-Batiz, R., and P. Romer. 1991. "Economic Integration and Endogenous Growth." Quarterty Journal of Economics 106: 531-556.

Roback, J. 1982. Wages, Rents, and the Quality of Life. Journal of Political Economy 90: 1257-78. 
Romer, P. 1986. "Increasing Returns and Long-Run Growth." Journal of Political Economy 94: $1002-37$.

Romer, P. 1990. "Endogenous Technological Change." Journal of Political Economy 98: S71S101.

Varian, H. 1984. Microeconomic Analysis. New York W.W. Norton.

Wei, S. 1993. "Open Door Policy and China's Rapid Growth: Evidence from City-Level Data" NBER Working Paper No. 4602.

White, HL 1980. "A Heteroskedasticity-Consistent Covariance Matrix Estimator and a Direct Test for Heteroskedasticity." Econometrica 48: 817-838.

Wilson, P.A. 1992. Exports and Local Development: Mexico's New Maquiladoras. Austin: University of Texas Press.

Young, A. 1991. "Leaming by Doing and the Dynamic Effects of International Trade." Quarterly Journal of Economics 106: 369-406. 
Table 1:

Average Tariffs and Import-License Requirements by Two-Dlgit Industry, 1984-1990 (percent)

\begin{tabular}{|c|c|c|c|c|c|c|c|c|}
\hline $\begin{array}{l}\text { Industry } \\
\text { (ISIC) }\end{array}$ & & 1984 & 1985 & 1986 & 1987 & 1988 & 1989 & 1990 \\
\hline $\begin{array}{l}\text { Food } \\
\text { Products }\end{array}$ & t & $\begin{array}{r}42.9 \\
100.0\end{array}$ & $\begin{array}{l}45.4 \\
80.1\end{array}$ & $\begin{array}{l}32.1 \\
62.2\end{array}$ & $\begin{array}{l}22.9 \\
33.3\end{array}$ & $\begin{array}{l}14.8 \\
20.8\end{array}$ & $\begin{array}{l}15.8 \\
20.6\end{array}$ & $\begin{array}{l}16.2 \\
16.8\end{array}$ \\
\hline $\begin{array}{l}\text { Textiles, } \\
\text { Apparel }\end{array}$ & t & $\begin{array}{l}38.6 \\
92.9\end{array}$ & $\begin{array}{l}43.2 \\
66.8\end{array}$ & $\begin{array}{l}40.4 \\
38.0\end{array}$ & $\begin{array}{l}26.6 \\
31.1\end{array}$ & $\begin{array}{r}16.8 \\
2.8\end{array}$ & $\begin{array}{c}16.6 \\
1.1\end{array}$ & $\begin{array}{r}16.7 \\
1.0\end{array}$ \\
\hline $\begin{array}{l}\text { Wood } \\
\text { Products }\end{array}$ & t & $\begin{array}{r}47.3 \\
100.0\end{array}$ & $\begin{array}{l}48.5 \\
75.6\end{array}$ & $\begin{array}{l}44.9 \\
25.7\end{array}$ & $\begin{array}{r}29.9 \\
0.0\end{array}$ & $\begin{array}{c}17.7 \\
0.0\end{array}$ & $\begin{array}{c}17.6 \\
0.0\end{array}$ & $\begin{array}{c}17.8 \\
0.0\end{array}$ \\
\hline $\begin{array}{l}\text { Paper, } \\
\text { Printing }\end{array}$ & t & $\begin{array}{l}33.7 \\
96.7\end{array}$ & $\begin{array}{l}36.5 \\
54.1\end{array}$ & $\begin{array}{l}34.8 \\
11.2\end{array}$ & $\begin{array}{r}23.7 \\
9.5\end{array}$ & $\begin{array}{l}7.7 \\
3.4\end{array}$ & $\begin{array}{r}10.1 \\
4.1\end{array}$ & $\begin{array}{l}9.9 \\
0.0\end{array}$ \\
\hline Chemicals & t & $\begin{array}{l}29.1 \\
85.7\end{array}$ & $\begin{array}{l}29.9 \\
54.0\end{array}$ & $\begin{array}{l}27.0 \\
21.1\end{array}$ & $\begin{array}{r}20.5 \\
4.8\end{array}$ & $\begin{array}{r}13.4 \\
0.0\end{array}$ & $\begin{array}{c}14.3 \\
0.0\end{array}$ & $\begin{array}{c}14.4 \\
0.0\end{array}$ \\
\hline Basic Metals & t & $\begin{array}{l}37.1 \\
99.0\end{array}$ & $\begin{array}{l}38.5 \\
53.1\end{array}$ & $\begin{array}{r}33.8 \\
5.2\end{array}$ & $\begin{array}{c}22.4 \\
0.0\end{array}$ & $\begin{array}{c}13.8 \\
0.0\end{array}$ & $\begin{array}{r}14.3 \\
0.0\end{array}$ & $\begin{array}{c}14.3 \\
0.0\end{array}$ \\
\hline $\begin{array}{l}\text { Non-Metallic } \\
\text { Minerals }\end{array}$ & $\begin{array}{l}\mathbf{t} \\
q\end{array}$ & $\begin{array}{l}13.6 \\
93.3\end{array}$ & $\begin{array}{l}16.7 \\
47.4\end{array}$ & $\begin{array}{c}18.4 \\
0.0\end{array}$ & $\begin{array}{c}13.8 \\
0.0\end{array}$ & $\begin{array}{l}7.9 \\
0.0\end{array}$ & $\begin{array}{r}11.0 \\
0.0\end{array}$ & $\begin{array}{c}11.0 \\
0.0\end{array}$ \\
\hline $\begin{array}{l}\text { Metal } \\
\text { Products }\end{array}$ & t & $\begin{array}{l}43.1 \\
90.7\end{array}$ & $\begin{array}{l}46.3 \\
74.8\end{array}$ & $\begin{array}{l}30.0 \\
54.7\end{array}$ & $\begin{array}{l}20.8 \\
51.4\end{array}$ & $\begin{array}{l}14.1 \\
42.7\end{array}$ & $\begin{array}{l}15.9 \\
44.1\end{array}$ & $\begin{array}{l}16.1 \\
44.1\end{array}$ \\
\hline $\begin{array}{l}\text { Other } \\
\text { Industries }\end{array}$ & $\begin{array}{l}\mathrm{t} \\
\mathrm{q}\end{array}$ & $\begin{array}{r}40.9 \\
100.0\end{array}$ & $\begin{array}{l}42.9 \\
50.0\end{array}$ & $\begin{array}{r}40.5 \\
0.0\end{array}$ & $\begin{array}{c}27.5 \\
0.0\end{array}$ & $\begin{array}{c}17.1 \\
0.0\end{array}$ & $\begin{array}{r}18.1 \\
0.0\end{array}$ & $\begin{array}{c}18.4 \\
0.0\end{array}$ \\
\hline
\end{tabular}

$t=$ Average tariff rate. $q=$ Average share of production subject to import-license requirements. Source: Unpublished data, Mexican Ministry of Trade and Industrial Promotion. 
Table 2: Manufacturing Employment Growth by Tro-Digit Industry, 1980-1985

\begin{tabular}{|l|c|c|}
\hline & \multicolumn{2}{|c|}{ Average Annual Employment Growth (\%) } \\
\hline \multicolumn{1}{|c|}{ Industry } & $1980-1985$ & $1985-1988$ \\
\hline All Manufacturing & 3.34 & -0.75 \\
\hline Food Products & 3.03 & 0.09 \\
\hline Textiles, Apparel & 1.66 & 2.21 \\
\hline Wood Products & 6.10 & 1.24 \\
\hline Paper, Printing & 1.46 & 0.49 \\
\hline Chemicals & 8.34 & -7.40 \\
\hline Non-metallic Minerals & 3.71 & -0.24 \\
\hline Basic Metals & 4.42 & -8.78 \\
\hline Metal Products & 2.20 & 0.60 \\
\hline Other Industries & -7.06 & 5.95 \\
\hline
\end{tabular}

Source: Autbor's calculations based on data from Censo Industrial, various years. 
Table 3: Reglonal Sbares of National Employment by Two-Dlglt lndustry, 1980 and 1988 (figures in percentages)

\begin{tabular}{|c|c|c|c|c|c|c|c|c|c|c|}
\hline \multirow[b]{2}{*}{ Industry } & \multicolumn{5}{|c|}{ Regional Share of National Employment, 1980} & \multicolumn{5}{|c|}{ Regional Share of National Employment, 1988} \\
\hline & Barder & North & Center & Mex. & Soulh & Borda & Norh & Center & Mex. & South \\
\hline All Manufacturing & 2095 & 5.25 & 25.48 & $44 A 4$ & 3.89 & 2821 & 6.78 & 27.26 & 33.17 & 4.58 \\
\hline Food Produces & 17.70 & 10.59 & 3392 & 28.70 & 9.10 & 18.51 & 10.81 & 3523 & 25.64 & 9.81 \\
\hline Texiles, Apparel & 1129 & 4.98 & 35.12 & 43.92 & 469 & 18.04 & 758 & 38.08 & 33.61 & 268 \\
\hline Wood Products & 19.18 & 14.65 & 2030 & 36.90 & 8.97 & 25.72 & 17.03 & 24,86 & 20.62 & 11.78 \\
\hline Paper, Printing & 13.89 & 3.61 & $13 A 7$ & 65.14 & 391 & 1897 & 6.04 & 16.10 & 54.25 & 464 \\
\hline Chernicals & 1459 & 1.78 & 26.31 & 55.73 & 1.60 & 16.56 & 1.77 & 31.07 & 45.75 & 4.85 \\
\hline Non-rmet. Minerals & 32.08 & 529 & 23.85 & 34.55 & 4.24 & 31.77 & 6.60 & 29.60 & 26.11 & 591 \\
\hline Basic Metals & 49.22 & 252 & 1840 & 29.82 & 0.05 & 40.08 & 7.18 & 23,45 & 29.13 & 0.15 \\
\hline Melal Products & 2690 & 2.76 & 1890 & 50.71 & 0.73 & 46.02 & 4.16 & 1688 & 32.01 & 0.92 \\
\hline Other Industriex & 15.61 & 0.85 & 13.06 & 69.19 & 128 & 30.56 & 2.67 & 896 & 55.11 & 2.70 \\
\hline
\end{tabular}

Source: Authors calculations based on dale from Censo Industrial, various years. 
Table 4: Average Anaual Relative Employment Growth by Reglon and Two-Digit Industry, 1980-1988

\begin{tabular}{|c|c|c|c|c|c|c|c|c|c|c|}
\hline \multirow[b]{2}{*}{ Industry } & \multicolumn{5}{|c|}{ Relative Employment Orounth (\%), 1980-1985 } & \multicolumn{5}{|c|}{ Relative Employment Growth (\%), 1985-1988 } \\
\hline & Border & North & Center & Mex. & South & Border & North & Center & Mex. & South \\
\hline All Manufachring & 2.03 & 3.88 & 3.05 & -3.76 & 0.33 & 653 & 2.10 & -2.82 & -348 & 4.87 \\
\hline Food Products & 127 & 1.77 & 0.09 & -156 & -0.34 & -0.63 & -224 & 1.11 & -1.16 & 308 \\
\hline Textiles, Apparel & 2.34 & 3.56 & 3.17 & -3.49 & -6.89 & 11.74 & 8.09 & -2.58 & -3.10 & -7.14 \\
\hline Wood Products & 430 & 4.75 & 0.73 & -4.80 & -3.40 & 2.61 & -289 & 555 & -11.41 & 14.76 \\
\hline Paper, Printing & 2.78 & 638 & 590 & -2.47 & -2.53 & 5.79 & 6.54 & -3.88 & -1.98 & 9.97 \\
\hline Chemicals & -0.27 & +199 & 697 & 4.49 & 13.42 & 4.68 & 3.15 & -6.08 & 1.61 & 14.73. \\
\hline Non-met. Minerals & -2.28 & 228 & 584 & +4.00 & 4.18 & $3 A 7$ & 3.62 & -253 & -2.67 & 4.15 \\
\hline Basic Metals & -394 & 15.64 & 5.74 & -0.40 & 40.08 & -028 & 8.84 & $-1 A 7$ & -0.11 & -2755 \\
\hline Metal Products & 4.88 & 7.73 & 1.74 & 4.79 & 7.69 & 9.77 & 0.75 & -6.66 & .735 & 491 \\
\hline Other Industries & 7.43 & 16.82 & -9.11 & -127 & 10.42 & 999 & 999 & 2.62 & -5.47 & 753 \\
\hline
\end{tabular}

Source: Author's calculations based on data from Censo Industrial, various years 
Table 5: Vartable definitions

(1) Relative employment growth

$$
\begin{aligned}
& \ln \left(L_{p \rho}\right)-\ln \left(L_{p}\right)-\left[\ln \left(L_{\beta}\right)-\ln \left(L_{j}\right)\right] \\
& \ln \left(\frac{R E M / L_{p}}{R E K / L_{p}}\right) \\
& \ln \left(\frac{L_{p} / E N T_{p}}{L_{\rho} / E S T_{p}}\right)
\end{aligned}
$$

(2) Relative wage

(3) Relative establishment size

(4) Relative female share of labor force

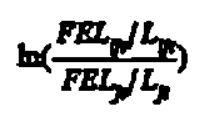

(5) Within-industry agglomeration

$$
\begin{aligned}
& \ln \left(\frac{L_{1} / L_{2}}{L_{j} / L_{2}}\right) \\
& \ln \left(\frac{L_{1} / L_{3}}{L_{2} / 5}\right)
\end{aligned}
$$

(6) Related-industry agglomeration

(7) Relative industrial diversity

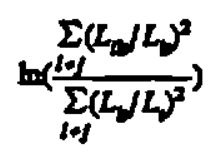

(8) Relative transport costs

$$
\ln \left(\frac{T_{i}}{\sum_{1} r_{i}}\right)
$$

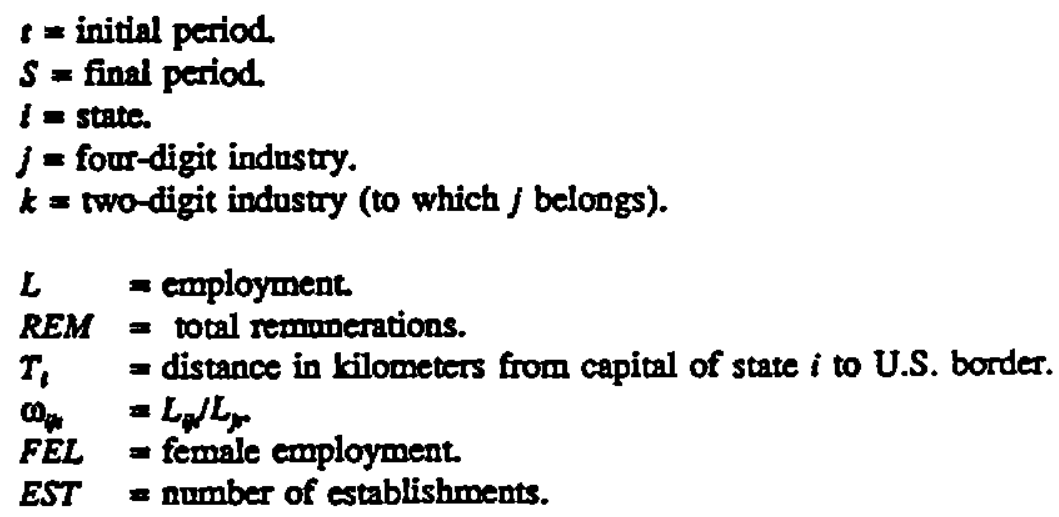


Table 6: Variable Means and Standard Errors

\begin{tabular}{|c|c|c|c|c|}
\hline \multirow{2}{*}{$\begin{array}{c}\text { Varfable } \\
\text { (all variables are logs) }\end{array}$} & \multicolumn{2}{|c|}{$\begin{array}{c}1980-1985 \\
\text { (observations }=1,151 \text { ) }\end{array}$} & \multicolumn{2}{|c|}{$\begin{array}{c}1985-1988 \\
\text { (observations }=1.110)\end{array}$} \\
\hline & Mean & Std. Er. & Mean & Std. Err. \\
\hline Relative employment growth & .013 & .182 & .004 & .276 \\
\hline Relative wage & -514 & .689 & -.431 & .656 \\
\hline Relative exablishment size & -.468 & 1.112 & -397 & 1.042 \\
\hline Relative female labor force & -.204 & .735 & -212 & .735 \\
\hline Within-industry agglomerition & -353 & 1260 & .182 & 988 \\
\hline Relnted-industry agglomeration & 221 & 1.110 & -325 & 1.185 \\
\hline Reletive industrial diversity & 965 & .439 & 915 & .420 \\
\hline Relative distance to U.S. & -382 & 1342 & .357 & 1.344 \\
\hline
\end{tabular}


Tablo 7t Regreation Resultu on Steto-Industry Relativo Employment Growth, 1980-1985

\begin{tabular}{|c|c|c|c|c|c|c|c|c|c|c|c|c|}
\hline Variables & (1. & (1b) & (2a) & (2.b) & (3a) & (3b) & (4s) & $(4 b)$ & $(5 \Omega)$ & (5.b) & (6A) & (6.b) \\
\hline $\begin{array}{l}\text { Relative } \\
\text { wago }\end{array}$ & $\begin{array}{c}0032 \\
(0103)\end{array}$ & $\begin{array}{l}.0015 \\
(.0122)\end{array}$ & $\begin{array}{l}-.0024 \\
(0101)\end{array}$ & $\begin{array}{l}.0005 \\
(.0119)\end{array}$ & $\begin{array}{l}-0055 \\
(0097)\end{array}$ & $\begin{array}{l}-0045 \\
(.0114)\end{array}$ & $\begin{array}{l}.0032 \\
(0107)\end{array}$ & $\begin{array}{l}.0019 \\
(0121)\end{array}$ & $\begin{array}{l}.0026 \\
(.0103)\end{array}$ & $\begin{array}{l}.0015 \\
(0122)\end{array}$ & $\begin{array}{l}-0048 \\
(0101)\end{array}$ & $\begin{array}{l}.0029 \\
(0114)\end{array}$ \\
\hline $\begin{array}{l}\text { Relative } \\
\text { establish. } \\
\text { size }\end{array}$ & $\begin{array}{l}-0491^{\circ} \\
(0075)\end{array}$ & $\begin{array}{l}-0582 \\
(0079)\end{array}$ & $\begin{array}{l}.0145 \\
(.0092)\end{array}$ & $\begin{array}{l}-.0184 \\
(0112)\end{array}$ & $\begin{array}{l}-.0176^{\circ} \\
(008 \mathrm{I})\end{array}$ & $\begin{array}{l}-0222 \\
(0093)\end{array}$ & $\begin{array}{l}-0491^{\prime} \\
(0077)\end{array}$ & $\begin{array}{l}-0601^{\circ} \\
(0083)\end{array}$ & $\begin{array}{l}-.0498^{*} \\
(.0075)\end{array}$ & $\begin{array}{l}-0582^{\prime} \\
(0080)\end{array}$ & $\begin{array}{l}-0101 \\
(0093)\end{array}$ & $\begin{array}{l}-0125 \\
(0109)\end{array}$ \\
\hline $\begin{array}{l}\text { Relative } \\
\text { female } \\
\text { labor }\end{array}$ & $\begin{array}{c}.0105 \\
(0081)\end{array}$ & $\begin{array}{l}.0102 \\
(0081)\end{array}$ & $\begin{array}{l}.0071 \\
(.0080)\end{array}$ & $\begin{array}{l}0092 \\
(0079)\end{array}$ & $\begin{array}{c}.0003 \\
(0079)\end{array}$ & $\begin{array}{l}.0039 \\
(0080)\end{array}$ & $\begin{array}{l}.0105 \\
(0082)\end{array}$ & $\begin{array}{l}0103 \\
(0081)\end{array}$ & $\begin{array}{l}.0095 \\
(.0082)\end{array}$ & $\begin{array}{c}.0102 \\
(0081)\end{array}$ & $\begin{array}{l}\infty 015 \\
(\infty 079)\end{array}$ & $\begin{array}{l}.0045 \\
(.0079)\end{array}$ \\
\hline $\begin{array}{l}\text { Wihin- } \\
\text { industry } \\
\text { agdiom. }\end{array}$ & & & $\begin{array}{l}-.0414^{4} \\
(.0062)\end{array}$ & $\begin{array}{l}-.0419^{\circ} \\
(.0079)\end{array}$ & & & & & & & $\begin{array}{l}-0149^{*} \\
(0074)\end{array}$ & $\begin{array}{l}-.02224 \\
(0096)\end{array}$ \\
\hline $\begin{array}{l}\text { Related. } \\
\text { industry } \\
\text { agglom. }\end{array}$ & & & & & $\begin{array}{l}.0513^{6} \\
(0064)\end{array}$ & $\begin{array}{l}.0504^{*} \\
(0070)\end{array}$ & & & & & $\begin{array}{l}0422 \\
(0078)\end{array}$ & $\begin{array}{l}.0425 \\
(.0082)\end{array}$ \\
\hline $\begin{array}{l}\text { Relative } \\
\text { industrial } \\
\text { diversity }\end{array}$ & & & & & & & $\begin{array}{l}-0007 \\
(0127)\end{array}$ & $\begin{array}{l}.0414 \\
(.0287)\end{array}$ & & & $\begin{array}{l}.0074 \\
(0123)\end{array}$ & $\begin{array}{l}-.1271^{\prime} \\
(0290)\end{array}$ \\
\hline $\begin{array}{l}\text { Relative } \\
\text { distance } \\
\text { to US. }\end{array}$ & & & & & & & & & $\begin{array}{l}. .0046 \\
(.0045)\end{array}$ & $\begin{array}{c}.0107 \\
(.0101)\end{array}$ & $\begin{array}{l}.0011 \\
(0045)\end{array}$ & $\begin{array}{l}.0223^{\circ} \\
(0097)\end{array}$ \\
\hline $\begin{array}{l}\text { Fixed } \\
\text { effects }\end{array}$ & no & yes & no & yes. & no & yes & no & yes & no & yes & no & yes \\
\hline Adj. $R^{2}$ & .084 & .151 & .126 & .177 & .149 & 200 & .083 & .151 & .084 & .151 & .151 & 208 \\
\hline No. obs. & 1151 & 1151 & 1151 & 1151 & 1151 & IISI & 1151 & tIS1 & 1151 & IIsI & 1151 & 1151 \\
\hline
\end{tabular}

-Indicales tignificance at the .05 level. Indicates significance at the .01 kvel. Hetcroskedasticity-consistent standard eron in partentheses. 
Table Ai Rezressbon Reaulte on State-Induatry Relative Emplojmest Gromth, 1985-1928

\begin{tabular}{|c|c|c|c|c|c|c|c|c|c|c|c|c|}
\hline Variables & (1a) & (1 b) & (2n) & (2b) & (3a) & (3b) & (4A) & $(4 b)$ & $\left(S_{n}\right)$ & (Sb) & (6n) & (6b) \\
\hline $\begin{array}{l}\text { Relative } \\
\text { wage }\end{array}$ & $\begin{array}{l}.0239 \\
(0166) \\
\end{array}$ & $\begin{array}{l}.0285 \\
\text { (0195) }\end{array}$ & $\begin{array}{l}.0213 \\
(0169)\end{array}$ & $\begin{array}{l}.0276 \\
(0198)\end{array}$ & $\begin{array}{l}0176 \\
(0171)\end{array}$ & $\begin{array}{l}.0227 \\
(.0209)\end{array}$ & $\begin{array}{l}.0246 \\
(0170)\end{array}$ & $\begin{array}{l}.0304 \\
(0195) \\
\end{array}$ & $\begin{array}{l}.0175 \\
(0167) \\
\end{array}$ & $\begin{array}{l}0285 \\
(0195)\end{array}$ & $\begin{array}{l}0140 \\
(0174)\end{array}$ & $\begin{array}{l}.0247 \\
(0209)\end{array}$ \\
\hline $\begin{array}{l}\text { Relative } \\
\text { establish. } \\
\text { stzo }\end{array}$ & $\begin{array}{l}-.0797 \\
(.0134)\end{array}$ & $\begin{array}{l}-.1040^{\circ} \\
(0139)\end{array}$ & $\begin{array}{l}-.0605^{\circ} \\
(.0144)\end{array}$ & $\begin{array}{l}-.0868^{\circ} \\
(0189)\end{array}$ & $\begin{array}{l}-.0542 \\
(0133)\end{array}$ & $\begin{array}{l}-0724 \\
(016 \mathrm{t})\end{array}$ & $\begin{array}{l}-0795^{\circ} \\
(0134)\end{array}$ & $\begin{array}{l}-.10735 \\
(.0144)\end{array}$ & $\begin{array}{l}-0838^{*} \\
(0134)\end{array}$ & $\begin{array}{l}-.1040^{\circ} \\
(0139)\end{array}$ & $\begin{array}{l}-067^{+} \\
(0141)\end{array}$ & $\begin{array}{l}-0814^{\circ} \\
(0193)\end{array}$ \\
\hline $\begin{array}{l}\text { Relative } \\
\text { female } \\
\text { labor }\end{array}$ & $\begin{array}{l}.0814^{*} \\
(0159)\end{array}$ & $\begin{array}{l}.0690^{\circ} \\
(.0158)\end{array}$ & $\begin{array}{l}.0781^{\circ} \\
(.0160)\end{array}$ & $\begin{array}{l}.0690^{b} \\
(0158)\end{array}$ & $\begin{array}{l}.0722^{*} \\
(0160)\end{array}$ & $\begin{array}{l}.0636^{\circ} \\
(0159)\end{array}$ & $\begin{array}{l}.0818 \\
(0160)\end{array}$ & $\begin{array}{l}.0695^{\circ} \\
(0158)\end{array}$ & $\begin{array}{l}.0704 \\
(0160)\end{array}$ & $\begin{array}{l}.0690^{\circ} \\
(0158)\end{array}$ & $\begin{array}{l}.0636^{\circ} \\
(0161)\end{array}$ & $\begin{array}{l}0635^{\circ} \\
(0159)\end{array}$ \\
\hline $\begin{array}{l}\text { Wihin } \\
\text { industry } \\
\text { ngglom. }\end{array}$ & & & $\begin{array}{l}-.0234^{\circ} \\
(.0100)\end{array}$ & $\begin{array}{l}-.0177 \\
(.0132)\end{array}$ & & & & & & & $\begin{array}{l}.0151 \\
(0112)\end{array}$ & $\begin{array}{l}0088 \\
(0145)\end{array}$ \\
\hline $\begin{array}{l}\text { Related- } \\
\text { industry } \\
\text { agglom. }\end{array}$ & & & & & $\begin{array}{l}0445^{\circ} \\
(0132)\end{array}$ & $\begin{array}{l}.0463 \\
(.0136)\end{array}$ & & & & & $\begin{array}{l}0485 * \\
(0153)\end{array}$ & $\frac{0514^{\circ}}{(0147)}$ \\
\hline $\begin{array}{l}\text { Relative } \\
\text { industrial } \\
\text { diversily }\end{array}$ & & & & & & & $\begin{array}{l}.0070 \\
(0171)\end{array}$ & $\begin{array}{l}.0551 \\
(0533)\end{array}$ & & & $\begin{array}{l}.0150 \\
(0169)\end{array}$ & $\begin{array}{l}-.0649 \\
(0578)\end{array}$ \\
\hline $\begin{array}{l}\text { Relative } \\
\text { distance } \\
\text { to U.S. }\end{array}$ & & & & & & & & & $\begin{array}{l}.0341^{\circ} \\
(0062)\end{array}$ & $\begin{array}{l}-0303^{\circ} \\
(0131)\end{array}$ & $\begin{array}{l}-.0332 * \\
(0062)\end{array}$ & $\begin{array}{l}-.0230 \\
(0137)\end{array}$ \\
\hline $\begin{array}{l}\text { Fixed } \\
\text { effects }\end{array}$ & no & yes & no & yes & no & yes & no & yes & no & yes: & no & yes \\
\hline Adj. $\mathbf{R}^{\mathbf{z}}$ & .104 & .174 & .108 & .175 & .120 & .189 & .103 & .174 & .129 & .174 & .142 & .189 \\
\hline No. obs. & 1116 & 1116 & 1116 & 1116 & 1116 & 1116 & 1116 & 1116 & 1116 & 1116 & 1116 & 1116 \\
\hline
\end{tabular}

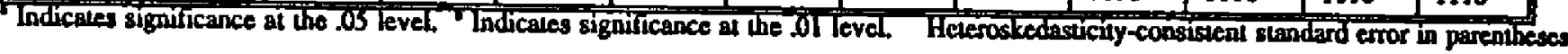


Table 9: Regresalon Resplts on Pooled Sample

\begin{tabular}{|c|c|c|c|c|}
\hline Variable & (1.a) & (1.b) & $(2, a)$ & (2.b) \\
\hline Relative wage & $\begin{array}{c}.0055 \\
(.0102) \\
\end{array}$ & $\begin{array}{r}.0033 \\
(.0120) \\
\end{array}$ & $\begin{array}{l}-.0054 \\
(.0101)\end{array}$ & $\begin{array}{l}-.0016 \\
(.0117) \\
\end{array}$ \\
\hline $\begin{array}{l}\text { Relative establishment } \\
\text { size }\end{array}$ & $\begin{array}{l}-.0492 \\
(.0076)\end{array}$ & $\begin{array}{l}-.0680^{\circ} \\
(.0081)\end{array}$ & $\begin{array}{l}-.0094 \\
(.0092)\end{array}$ & $\begin{array}{l}-.0224^{4} \\
(.0110) \\
\end{array}$ \\
\hline $\begin{array}{l}\text { Relative female labor } \\
\text { force }\end{array}$ & $\begin{array}{c}.0111 \\
(.0081) \\
\end{array}$ & $\begin{array}{c}.0061 \\
(.0087)\end{array}$ & $\begin{array}{c}.0013 \\
(.0080)\end{array}$ & $\begin{array}{c}.0027 \\
(.0083)\end{array}$ \\
\hline $\begin{array}{l}\text { Wirhin-industry } \\
\text { agglomeration }\end{array}$ & & & $\begin{array}{l}-.0149 \\
(.0074)\end{array}$ & $\begin{array}{l}-.0152 \\
(.0091) \\
\end{array}$ \\
\hline $\begin{array}{l}\text { Related-industry } \\
\text { agglomeration }\end{array}$ & & & $\begin{array}{r}.0424^{\circ} \\
(.0078) \\
\end{array}$ & $\begin{array}{r}.0441^{\circ} \\
(.0082)\end{array}$ \\
\hline $\begin{array}{l}\text { Relative industrial } \\
\text { diversity }\end{array}$ & & & $\begin{array}{c}.0145 \\
(.0111) \\
\end{array}$ & $\begin{array}{l}-.0243 \\
(.0218)\end{array}$ \\
\hline Relative distance to U.S. & & & $\begin{array}{c}.0006 \\
(.0044)\end{array}$ & $\begin{array}{l}.0296 \\
(.1202) \\
\end{array}$ \\
\hline Relative wage"year85 & $\begin{array}{c}.0162 \\
(.0179) \\
\end{array}$ & $\begin{array}{c}.0211 \\
(.0186)\end{array}$ & $\begin{array}{c}.0202 \\
(.0202)\end{array}$ & $\begin{array}{l}.02222 \\
(.0197)\end{array}$ \\
\hline $\begin{array}{l}\text { Reladive establishment } \\
\text { size"year85 }\end{array}$ & $\begin{array}{l}-.0305 \\
(.0154) \\
\end{array}$ & $\begin{array}{l}-.0317 \\
(.0146) \\
\end{array}$ & $\begin{array}{l}-.0584 \\
(.0169) \\
\end{array}$ & $\begin{array}{l}-.0558^{*} \\
(.0170) \\
\end{array}$ \\
\hline $\begin{array}{l}\text { Relative female labor } \\
\text { forcetyear } 85\end{array}$ & $\begin{array}{r}.0690^{\circ} \\
(.0177)\end{array}$ & $\begin{array}{r}.0668 \\
(.0172) \\
\end{array}$ & $\begin{array}{r}.0626^{\circ} \\
(.0180) \\
\end{array}$ & $\begin{array}{r}0.0504^{\circ} \\
(.0173) \\
\end{array}$ \\
\hline $\begin{array}{l}\text { Within-industry } \\
\text { agglomemation "year } 85\end{array}$ & & & $\begin{array}{r}.0300 \\
(.0134)\end{array}$ & $\begin{array}{c}.0258 \\
(.0132) \\
\end{array}$ \\
\hline $\begin{array}{l}\text { Related-induatry } \\
\text { agglomeration "year85 }\end{array}$ & & & $\begin{array}{c}.0058 \\
(.0173)\end{array}$ & $\begin{array}{l}.0069 \\
(.0164)\end{array}$ \\
\hline $\begin{array}{l}\text { Relarive industrial } \\
\text { diversity year85 }\end{array}$ & & & $\begin{array}{l}. .0070 \\
(.0123)\end{array}$ & $\begin{array}{l}-.0011 \\
(.0223)\end{array}$ \\
\hline $\begin{array}{l}\text { Reladve distance to } \\
\text { US. -year8S }\end{array}$ & & & $\begin{array}{l}-.0332 \\
(.0075) \\
\end{array}$ & $\begin{array}{l}.0340^{\circ} \\
(.0075)\end{array}$ \\
\hline $\begin{array}{l}\text { P-statistic on year8s } \\
\text { coefficients }\end{array}$ & $5.78^{\circ}$ & $5.7+$ & $5.85^{\circ}$ & $5.7 \%$ \\
\hline Fixed effects & no & yes & $\infty$ & yes \\
\hline Adjusted $\mathrm{R}^{2}$ & .098 & .136 & .145 & .169 \\
\hline Number of observations & 2207 & 2267 & 2267 & 2267 \\
\hline
\end{tabular}

Indicates significance at the 05 evel. Indicates significance at the .0I level Heterostedasticity-consistent standard etros in parentheseas. year85 is a dummy variable that takes a value of one if the year is 1985 . 
Table 10: Regresulon Resolta Excludiog Merjeo City Region

\begin{tabular}{|c|c|c|c|c|}
\hline Variable & (1.s) & (1.b) & (2s) & (2.b) \\
\hline Relative wage & $\begin{array}{r}.0138 \\
(.0114) \\
\end{array}$ & $\begin{array}{r}.0050 \\
(.0133) \\
\end{array}$ & $\begin{array}{c}.0013 \\
(.0113)\end{array}$ & $\begin{array}{c}.0011 \\
(.0129)\end{array}$ \\
\hline $\begin{array}{l}\text { Relative } \\
\text { establishment sizo }\end{array}$ & $\begin{array}{l}-.0513^{\circ} \\
(.0080)\end{array}$ & $\begin{array}{r}-.0686^{\circ} \\
(.0084)\end{array}$ & $\begin{array}{l}-.0087 \\
(.0097)\end{array}$ & $\begin{array}{l}-.0212 \\
(.0115) \\
\end{array}$ \\
\hline $\begin{array}{l}\text { Relative femalo } \\
\text { laber force }\end{array}$ & $\begin{array}{c}0138 \\
(.0084)\end{array}$ & $\begin{array}{c}.0079 \\
(0089)\end{array}$ & $\begin{array}{c}0009 \\
(0082)\end{array}$ & $\begin{array}{l}.0046 \\
(0086)\end{array}$ \\
\hline $\begin{array}{l}\text { Within-industry } \\
\text { sggiomention }\end{array}$ & & & $\begin{array}{l}-.0162 \\
(.0077)\end{array}$ & $\begin{array}{l}-.0155 \\
(.0099) \\
\end{array}$ \\
\hline $\begin{array}{l}\text { Reluted-industry } \\
\text { agglomeration }\end{array}$ & & & $\begin{array}{r}.0445^{\circ} \\
(.0080)\end{array}$ & $\begin{array}{l}.0464^{\circ} \\
(.0085)\end{array}$ \\
\hline $\begin{array}{l}\text { Relative indostrial } \\
\text { diversity }\end{array}$ & & & $\begin{array}{c}.0105 \\
(.0123)\end{array}$ & $\begin{array}{l}-.0155 \\
(.0230) \\
\end{array}$ \\
\hline $\begin{array}{l}\text { Relative distance } \\
\text { is US. }\end{array}$ & . & & $\begin{array}{r}.0017 \\
(.0045)\end{array}$ & $\begin{array}{c}.0349 \\
(.1278)\end{array}$ \\
\hline $\begin{array}{l}\text { Relative } \\
\text { wagetyear85 }\end{array}$ & $\begin{array}{r}.0163 \\
(.0188) \\
\end{array}$ & $\begin{array}{l}.0272 \\
(.0196)\end{array}$ & $\begin{array}{r}.0215 \\
(.0212) \\
\end{array}$ & $\begin{array}{l}.0256 \\
(0205)\end{array}$ \\
\hline $\begin{array}{l}\text { Relative establish. } \\
\text { stootyear85 }\end{array}$ & $\begin{array}{l}. .0334 \\
(.0161)\end{array}$ & $\begin{array}{l}-.0350 \\
(.0150) \\
\end{array}$ & $\begin{array}{l}-.0650^{\circ} \\
(.0176) \\
\end{array}$ & $\begin{array}{l}.0622^{6} \\
(.0177) \\
\end{array}$ \\
\hline $\begin{array}{l}\text { Relative female } \\
\text { labor force year8s }\end{array}$ & $\begin{array}{r}.0723^{\circ} \\
(.0182) \\
\end{array}$ & $\begin{array}{l}.0710^{\circ} \\
(.0177)\end{array}$ & $\begin{array}{r}.0670^{\circ} \\
(.0184) \\
\end{array}$ & $\begin{array}{r}.0646^{\circ} \\
(.0177)\end{array}$ \\
\hline $\begin{array}{l}\text { Withia-inderty ag- } \\
\text { glomeration tyear8s }\end{array}$ & & & $\begin{array}{r}.0303^{\circ} \\
(.0140) \\
\end{array}$ & $\begin{array}{r}.0247 \\
(.0140) \\
\end{array}$ \\
\hline $\begin{array}{l}\text { Related-industry ag- } \\
\text { glomeration "year85 }\end{array}$ & & & $\begin{array}{r}.0002 \\
(.0175)\end{array}$ & $\begin{array}{c}.0009 \\
(.0167) \\
\end{array}$ \\
\hline $\begin{array}{l}\text { Relative industrial } \\
\text { diversity year8s }\end{array}$ & & & $\begin{array}{l}. .0057 \\
(.0126) \\
\end{array}$ & $\begin{array}{l}. .0063 \\
(.0246) \\
\end{array}$ \\
\hline $\begin{array}{l}\text { Relative distance to } \\
\text { U.S." year85 }\end{array}$ & & & $\begin{array}{l}-.0328^{\circ} \\
(.0075) \\
\end{array}$ & $\begin{array}{l}.0332^{\circ} \\
(.0076) \\
\end{array}$ \\
\hline $\begin{array}{l}\text { F-statistic on year8s } \\
\text { coefficient }\end{array}$ & $6.03^{\circ}$ & $6.42^{\circ}$ & $6.06^{\circ}$ & $5.94^{\circ}$ \\
\hline Fixed effects & no & yes & no & yes \\
\hline Adjusted $R^{2}$ & .104 & .146 & .151 & .178 \\
\hline Na of observations & 2080 & 2080 & 2080 & 2080 \\
\hline
\end{tabular}

Indicates signiticance at the .0S level. Indicates signiricance at the .01 level Heteroskedasticity-conststent standard error in parentheses. 
Table 11: Regression Results Excloding Border Rezlon

\begin{tabular}{|c|c|c|c|c|}
\hline Variable & (1.2) & (1.b) & (2.2) & (2.b) \\
\hline Relative wage & $\begin{array}{c}.0029 \\
(.0108)\end{array}$ & $\begin{array}{c}.0053 \\
(.0128)\end{array}$ & $\begin{array}{l}-.0088 \\
(.0110)\end{array}$ & $\begin{array}{l}-.0039 \\
(.0123)\end{array}$ \\
\hline $\begin{array}{l}\text { Relarive } \\
\text { extablishment size }\end{array}$ & $\begin{array}{l}-.0539^{\circ} \\
(.0082)\end{array}$ & $\begin{array}{l}-.0768^{\circ} \\
(.0090)\end{array}$ & $\begin{array}{l}-.0164 \\
(.0099)\end{array}$ & $\begin{array}{l}-.0295 \\
(.0119)\end{array}$ \\
\hline $\begin{array}{l}\text { Relative female } \\
\text { labor force }\end{array}$ & $\begin{array}{c}.0073 \\
(.0090)\end{array}$ & $\begin{array}{c}.0013 \\
(.0098)\end{array}$ & $\begin{array}{l}-.0017 \\
(.0087)\end{array}$ & $\begin{array}{l}.0012 \\
(.0094)\end{array}$ \\
\hline $\begin{array}{l}\text { Within-industry } \\
\text { agglomeratlon }\end{array}$ & & & $\begin{array}{l}-.0182^{2} \\
(.0081)\end{array}$ & $\begin{array}{l}-.0213^{\circ} \\
(.0102)\end{array}$ \\
\hline $\begin{array}{l}\text { Related-industry } \\
\text { agglomeration }\end{array}$ & & & $\begin{array}{r}.03624 \\
(.0084)\end{array}$ & $\begin{array}{l}.0375^{\circ} \\
(.0089)\end{array}$ \\
\hline $\begin{array}{l}\text { Relative industrial } \\
\text { diversity }\end{array}$ & & & $\begin{array}{l}-.0083 \\
(.0119) \\
\end{array}$ & $\begin{array}{l}-.0388 \\
(.0229) \\
\end{array}$ \\
\hline $\begin{array}{l}\text { Relative distance } \\
\text { to US. }\end{array}$ & . & & $\begin{array}{c}.0053 \\
(.0073)\end{array}$ & $\begin{array}{r}.0046 \\
(.1417)\end{array}$ \\
\hline $\begin{array}{l}\text { Relattve } \\
\text { wagetyear8s }\end{array}$ & $\begin{array}{c}0102 \\
(.0195)\end{array}$ & $\begin{array}{c}.0120 \\
(.0200)\end{array}$ & $\begin{array}{c}0177 \\
(0220)\end{array}$ & $\begin{array}{l}.0229 \\
(.0214)\end{array}$ \\
\hline $\begin{array}{l}\text { Relative establish. } \\
\text { sizetyear85 }\end{array}$ & $\begin{array}{l}-.0261 \\
(.0174)\end{array}$ & $\begin{array}{l}-.0256 \\
(.0163)\end{array}$ & $\begin{array}{l}-.0476 \\
(.0187)\end{array}$ & $\begin{array}{l}-.0452 \\
(.0189)\end{array}$ \\
\hline $\begin{array}{l}\text { Relative female } \\
\text { labor force yearss }\end{array}$ & $\begin{array}{r}.0703^{2} \\
(.0202)\end{array}$ & $\begin{array}{r}.0670^{\circ} \\
(.0198)\end{array}$ & $\begin{array}{r}.0538^{\circ} \\
(.0200)\end{array}$ & $\begin{array}{l}.0613^{\circ} \\
(.0201)\end{array}$ \\
\hline $\begin{array}{l}\text { Within-indostry ag- } \\
\text { glomeration year85 }\end{array}$ & & & $\begin{array}{r}0186 \\
(.0190) \\
\end{array}$ & $\begin{array}{c}.0191 \\
(.0180) \\
\end{array}$ \\
\hline $\begin{array}{l}\text { Related-industry ag- } \\
\text { glomeration year85 }\end{array}$ & & & $\begin{array}{r}.0320^{\circ} \\
(.0148)\end{array}$ & $\begin{array}{r}.0264 \\
(.0146)\end{array}$ \\
\hline $\begin{array}{l}\text { Relative industrial } \\
\text { diversity*year85 }\end{array}$ & & & $\begin{array}{c}.0002 \\
(.0138)\end{array}$ & $\begin{array}{l}.0065 \\
(.0250)\end{array}$ \\
\hline $\begin{array}{l}\text { Relative distance to } \\
\text { US."year85 }\end{array}$ & & & $\begin{array}{l}-.0523^{\circ} \\
(.0125)\end{array}$ & $\begin{array}{l}-.0518^{6} \\
(.0122)\end{array}$ \\
\hline $\begin{array}{l}\text { R-statistic on year8s } \\
\text { coefficients }\end{array}$ & $438^{*}$ & $4.12^{b}$ & $4.81^{\circ}$ & $4.65^{\circ}$ \\
\hline Fixed effects & no & yes & no & yes \\
\hline Adjusted $\mathrm{R}^{2}$ & .106 & .146 & .158 & .183 \\
\hline Na. of observations & 1823 & 1823 & 1823 & 1823 \\
\hline
\end{tabular}

Indicates significance at the 005 tevel, Indicates significance at the .01 level. Heteroskedasticity-consistent standard eror in parentheses. 
Table 12: Retression Results on Selected Industries"

\begin{tabular}{|c|c|c|c|c|}
\hline Variable & (2a) & (2.b) & (2a) & (2.b) \\
\hline Relative wage & $\begin{array}{l}.0095 \\
(.0172)\end{array}$ & $\begin{array}{l}.0042 \\
(.0215) \\
\end{array}$ & $\begin{array}{l}-.0164 \\
(.0174) \\
\end{array}$ & $\begin{array}{l}-.0171 \\
(.0206)\end{array}$ \\
\hline $\begin{array}{l}\text { Relative } \\
\text { establishment size }\end{array}$ & $\begin{array}{l}.0540^{\circ} \\
(.0109)\end{array}$ & $\begin{array}{l}.0775 \\
(.0114)\end{array}$ & $\begin{array}{l}-.0055 \\
(.0140)\end{array}$ & $\begin{array}{l}-.0234 \\
(.0167)\end{array}$ \\
\hline $\begin{array}{l}\text { Reladve female } \\
\text { inber force }\end{array}$ & $\begin{array}{c}.0141 \\
(.0111)\end{array}$ & $\begin{array}{l}-.0001 \\
(.0117) \\
\end{array}$ & $\begin{array}{l}-.0017 \\
(.0100) \\
\end{array}$ & $\begin{array}{l}-.0053 \\
(.0110) \\
\end{array}$ \\
\hline $\begin{array}{l}\text { Whing-industry } \\
\text { agglomeration }\end{array}$ & & & $\begin{array}{l}. .0246^{\circ} \\
(.0118) \\
\end{array}$ & $\begin{array}{l}. .0217 \\
(.0133)\end{array}$ \\
\hline $\begin{array}{l}\text { Relined-industoy } \\
\text { agglomeration }\end{array}$ & & & $\begin{array}{l}.0392^{\circ} \\
(.0109)\end{array}$ & $\begin{array}{l}.0407 \\
(.0112)\end{array}$ \\
\hline $\begin{array}{l}\text { Relative industrial } \\
\text { diversity }\end{array}$ & & & $\begin{array}{l}. .0032 \\
(.0180)\end{array}$ & $\begin{array}{l}.0476 \\
(.0339)\end{array}$ \\
\hline $\begin{array}{l}\text { Relative distence } \\
\text { io U.S. }\end{array}$ & & & $\begin{array}{l}. .0047 \\
(.0065)\end{array}$ & $\begin{array}{l}.0235 \\
(.1398)\end{array}$ \\
\hline $\begin{array}{l}\text { Relative } \\
\text { wagetyear8s }\end{array}$ & $\begin{array}{l}.0083 \\
(.0280)\end{array}$ & $\begin{array}{c}.0054 \\
(.0304)\end{array}$ & $\begin{array}{l}.0076 \\
(.0306)\end{array}$ & $\begin{array}{l}.0182 \\
(.0314)\end{array}$ \\
\hline $\begin{array}{l}\text { Relative establish. } \\
\text { sizetyear85 }\end{array}$ & $\begin{array}{l}-.0192 \\
(.0208)\end{array}$ & $\begin{array}{l}-.0263 \\
(.0193)\end{array}$ & $\begin{array}{l}-.0656^{\circ} \\
(.0239)\end{array}$ & $\begin{array}{l}-.0700^{\circ} \\
(.0242)\end{array}$ \\
\hline $\begin{array}{l}\text { Relative female } \\
\text { labor force"year8s }\end{array}$ & $\begin{array}{l}.0785^{\circ} \\
(.0211)\end{array}$ & $\begin{array}{r}.0736^{\circ} \\
(.0212)\end{array}$ & $\begin{array}{r}.0695^{\circ} \\
(.0211)\end{array}$ & $\begin{array}{l}.0690^{\circ} \\
(.0213)\end{array}$ \\
\hline $\begin{array}{l}\text { Whin-indnstry ag- } \\
\text { glomeradion -year85 }\end{array}$ & & & $\begin{array}{r}0444 \\
(.0214)\end{array}$ & $\begin{array}{l}.0437^{\circ} \\
(.0212)\end{array}$ \\
\hline $\begin{array}{l}\text { Relned-industry ag- } \\
\text { glomeracion year8s }\end{array}$ & & & $\begin{array}{c}.0042 \\
(.0208)\end{array}$ & $\begin{array}{l}.0056 \\
(.0219)\end{array}$ \\
\hline $\begin{array}{l}\text { Relotive industrial } \\
\text { diversity year85 }\end{array}$ & & & $\begin{array}{l}-.0064 \\
(.0195)\end{array}$ & $\begin{array}{c}.0142 \\
(.0350)\end{array}$ \\
\hline $\begin{array}{l}\text { Reletive distance to } \\
\text { U.S. year85 }\end{array}$ & & . & $\begin{array}{l}-.0400^{\circ} \\
(.0110)\end{array}$ & $\begin{array}{l}-.0415^{\circ} \\
(.0109)\end{array}$ \\
\hline $\begin{array}{l}\text { P-statistic on year85 } \\
\text { coefficients }\end{array}$ & 4.67 & $425^{\circ}$ & $4.39^{\circ}$ & $4.38^{\circ}$ \\
\hline Fixed efiects & no & yea & no & yes \\
\hline Adjusted $\mathrm{R}^{2}$ & .097 & .141 & .152 & .169 \\
\hline No. of observations & 1334 & 1334 & 1334 & 1334 \\
\hline
\end{tabular}

Indicales significance at the .05 level. Indicates significance at the of level Heteroskedasticityconsistent standard entor in parentheses. - Excluded industries are ISIC 31, 34, 36, and 37. 